Spatially and intertemporally efficient waste management:

The costs of interstate flow control by Eduardo Ley" Molly K. Macauley ${ }^{\text {*t: }}$ Stephen W. Salant ${ }^{* * * *}$

DOCUMENTO DE TRABAJO 97-07

Mayo, 1997

FEDEA.

** Resources for the Future, Washington DC, USA.

*** University of Michigan, Ann Arbor MI, USA. 
Spatially and Intertemporally Efficient Waste Management: The Costs of Interstate Flow Control

\author{
Eduardo Ley \\ F.E.D.E.A., Madrid, Spain \\ Molly K. Macauley \\ Resources for the Future, Washington DC, USA \\ Stephen W. Salant \\ University of Michigan. Ann Arbor MI, USA
}

Version: May 3, 1997

Keywords. Solid Waste, Efficiency

JEL Classification System. C6, D6, Q3

Address. Eduardo Ley, FEDEA, Jorge Juan 46, ES-28001 Madrid. Phone: (+34-1) 435 0401. Fax: $(+34-1) 577$ 9575. Email: edley@bigfoot.com. 


\title{
Spatially and Intertemporally Efficient Waste Management: The Costs of Interstate Flow Control
}

\author{
Eduardo Ley \\ F.E.D.E.A., Madrid, Spain \\ Molly K. Macauley \\ Resources for the Future, Washington DC, USA \\ Stephen W. Salant \\ University of Michigan, Ann Arbor MI, USA
}

The growing trend in interstate shipments of solid waste in the United States is a topic of substantial public debate. There have been numerous Supreme Court decisions concerning the control of waste shipments in the context of the Tuterstate Commerce Clause and seveal recent Congressional proposals to exempt waste generation from the jurisdiction of that clause. To date, however, very little is known about the effects such proposed restrictions might have on the interstate waste market.

Our rescard evaluates the potential economic effects of public policies proposed to restrict flows of mumipal solid waste (MSW henceforth). "These restrictions indude local or state requirements stipulating where waste must be landfilled, prohibitions on the import or export of waste across state boundaries, quantitative limits on these fows. and extra foes levied on imported waste. We focus on the aggregate surplus loss (and its regional distribution) that would result from such controls. Such losses would arise because more distant or higher-cost disposal facilities would have to be used if lower-cost. choices are proscribed.

Some of the questions our paper addresses include: (1) If interstate trade in MSW is banned, what is the social surplus associated with the antarkic allocation which results? Are the changes in surphus likely to differ among regions of the country? If so, are somo better off and others worse of than before the ban? (2) If interstate trade is permitted but quantities of waste imports or exports are restricted, what are the effects on the public in various regions of the country? In the associated competitive equilitrium, (3) what are the effects on producers and consumers of such quantitative restrictions? (4) If higher fees are charged for waste disposal when the waste originaties outside the state, what are the conomic effects on different regions of the country, and on producers and consumers?

li. Ley was a fellow and S. Salant a Gibert White Visiting lellow at Resources for the future during the owly stages of this work. 'This reseach was supported by the U.S. Finvironmental protedion Agency Natimal Centor for linvinomental Research and Qmality Assurance grant \# R82 1365 and Resomeces for the luture. Responsibility for erors and opinions rests with the atulhors.

I Strictly speaking; two types of such restrictions on the flow of waste are the subject of current dobate: so-called flow control, and restrictions specifically on interstote shipments of waste. Both of these restrict the flow or shipment of waste, but flow control generally refers to within-stalie restriefions (even though these may also impact interstate shipments). On focus is on interstate restrictions. 
In Section 1, we offer some background information on MSW and the interstate waste market, and then briefy review proposed legislative developments to restrict interstate shipments of waste and the arguments underlying the debate over them. Sertion 2 presents a central planning model of interstate waste trade developed recently by Gaudet, Moreaux and Salant (1997). Their model characterizes the efficient allocation over time of spatially differentiated resources in finite supply such as the nation's wraste disposal facitilities. We add policy constraints to their theoretical model and then implement it on the computer. Because of data limitations, we take no account of psychic benefits communities may feel if imports of waste from other locales are reduced. Nor: do we account for other possible benefits such as reducing trasportation congestion and noise. We apply our computerized model to two regions of the United States, the Northcast and Midwest. These regions account for about $80 \%$ of interstate trade by volmme, and involve volumes large enough to be subject to restrictions proposed in pending legislation (for example, in a recently passed Senate bill (S. 534) described below two of the bill's thee allowable restrictions apply only to large volumes of waste exports or imports). We also focus on waste that is landfilled, as this is the disposal method for: most interstate waste. However, an important input in our model, and one to which its fesults are sensitive, is the cost of altemative disposal methods. We calibrate our model using publicly avalable data on waste generation, waste disposal and transportation costs, estimated demand elasticities for waste generation, and other infomation. We discuss these inputs to our simulation model in Section 3 and the resulting baseline simnulations in Section 4. We then impose varions restrictions on the model to investigate the effects of sereral recenty proposed constaints on interstate waste flows. Specifially, we andyze fou policies: (1) restrictions on the volume of waste exponts, (2) an outright prohibition of interstate shipments, (3) surcharges on imported waste, and (4) a combination of surcharges and volume-based restrictions. We estimate the offects of these restrictions on interstate waste fows, aggregate surplus loss, and the regional distribution of the changes in supplus. We also investigate the impact of such policies on producers and cousumers in the associated competitive equilibrim. We plesent these results in Sections 5 and 6. In Section 7, we offer some conclusions aloont restrictions on interstate waste flow.

\section{Background -- Municipal solid waste and interstate waste trade}

\subsection{Municipal Solid Waste}

Our focus on MSW refers generally to the everyday trash generated by houscholds. The definition of MSW varies among states and localities but it usually includes yard trimmings (which can account for a large tomage of waste) and excludes hazardous waste, construction and demolition debris, and industrial waste. Abont 306,866,000 tons of MSW were generated in the United States during 1994 (the most recent yeas: for which detailed data are available), or about one ton of waste per person that year. MSW generation has tended to increase about $5 \%$ per year in recent years. Historically, disposal of MSW has taken place at the neasest landfill, incinerator, or other disposal facility. For a variety of reasons, however, the amount of MSW transported across state boundaries has been increasing since the mid 1980s. According to the most recent data about interstate flows, almost all states routinely import and export some waste (47 
states export waste and 44 states import waste), not just to a neighboring state but frequently much longer distances (see figure 1). " This "interstate waste market" has handled an estimated 14,000,000 tons of MSW annually in recent years (about $5 \%$ of the total MSW generated). Although this volume may seem small, the transport costs associated with it amount to about $\$ 500$ million anmually. ${ }^{3}$

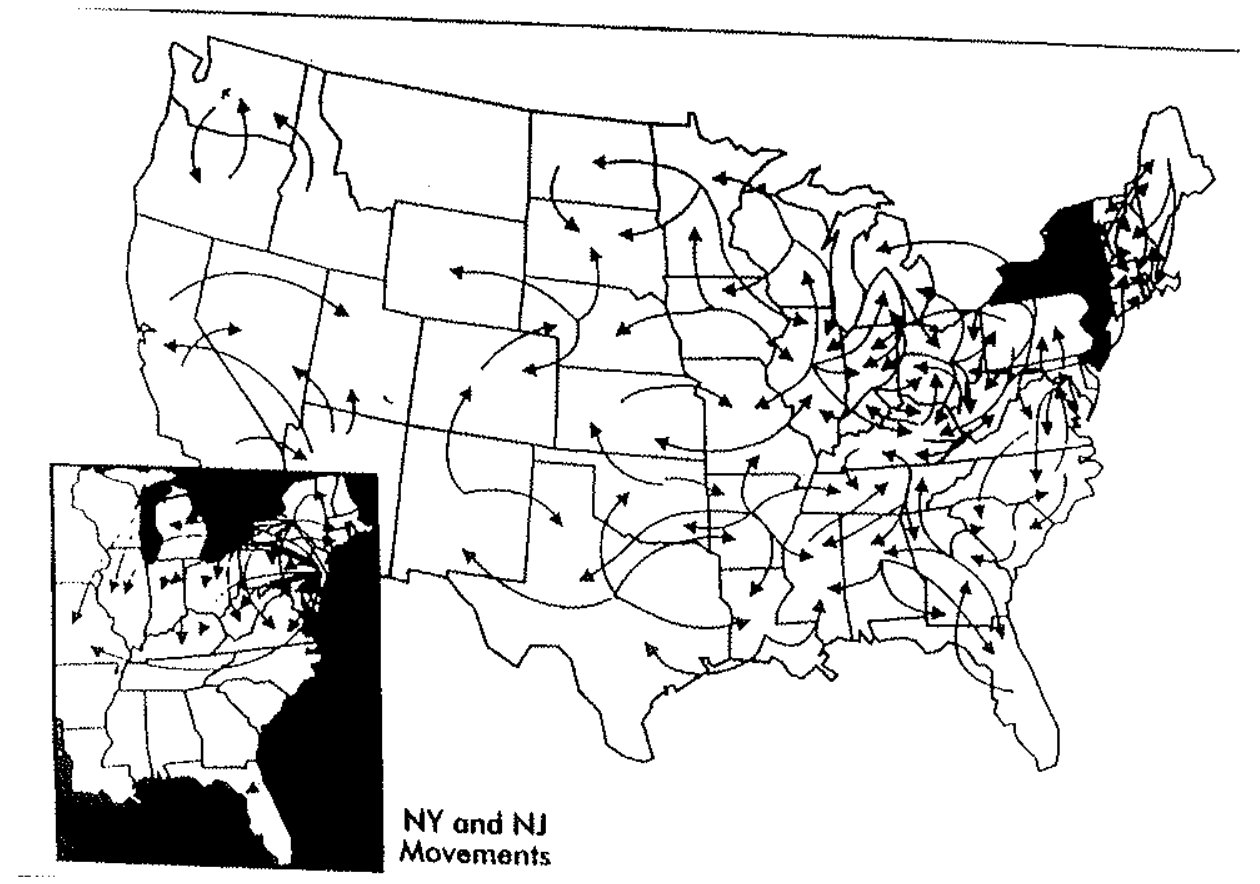

Fig. 1. Interstate fows of Municipal Solid Waste.

Somm: National Sold Waste Management Association (now Bmvirommental Industry Association) (1992): "Interstate Movement of Municipal Solid Waste". Waslington DC: National Solid Waste Management, Association, fobruary; p. 3.

The willingness to beas the transportation costs arises lasgely from significant differences among tipping fees (the charge per ton to unload a truck at a disposal facility) arcoss states." For instance, landfill tipping fees average $\$ 10$ in Nevada, $\$ 27$ in ()hio, and $\$ 75$ in New Jersey. These differences reflect several related factors, including the closing of many landfills and public opposition to expanding capacity at existing landfills or constructing new ones. For example, a trend in interstate waste transport from the Northeast to the Midwest developed during the early 1990 s because of the closing of many landfills in New York and New Jersey; and the inability of northeastem states to site new facilities. This caused a shaxp rise in the tip fee at the remaining facilities. During 1991-1992, the tipping fee at the Fresh Kills landfill, the only disposal facility in

\footnotetext{
2 the: map is for $1989 \cdots 1990$ but based on McCarthy (1995) these flow patterns appear to have contimued to the present.

3 Authos' calculations, available from anthors, based on average volume, distance transported and tamport costs.

1 Much of this discussion is based on Macauley, Salant, Walls, and lidelstein, 1993.
} 
New York City, rose from $\$ 80$ to $\$ 150$ per ton (it is now about $\$ 120$ ). Tipping fees in northeastern states typically average $\$ 50$ or more per ton. In contrast, the average tipping fee in midwestern states (major importers of waste) is significantly lower, averaging $\$ 25$ to $\$ 30$ per ton. Thus, even with transportation costs, it can remain cheaper in many cases for northeastem states to export refuse to landfills in the Midwest. For example, assuming transportation costs of ten to fifteen cents per ton mile, the per-ton cost of shipping waste from New York to Ohio is just $\$ 75$ to $\$ 95$, including Ohio's average tip fee of $\$ 25$ per tion.

The growing trend in interstate waste transport has been opposed by citizens' groups. envirommental organizations, state legislators, and others. They express concen about being a "dumping ground," the impact of landfill growth on local property values, and the limited capacity of local landfills. This opposition has led many states to ban, differentially charge, or impose other restrictions on imported waste. As of 1993,41 of the 48 contiguous states had considered or enacted legislation to restrict the fow of waste across their boundaries.

Most of these restrictions have been stuck down by the courts as violations of the Interstate Commerce Clause of the United States' Constitution. When state regulations place an "undue burden" on commeree, including the trade of waste, they are deened 10 be unconstitutional. In a landmark decision in May, 1994, the Suprene Court med 63 against a municipal ordinance that MSW generated within the state of Now York be managed at a designated waste processing facility financially backed by the town of Clarkstown (Carbone, Inc. v. Town of Clarkstown. ${ }^{5}$ The Court muled that the ordinane discriminates against interstate commerce even thongh it prohibits waste from being sent to other local waste transfer stations as well. The Juterstate Commere Chase does, however, empower Congress to allow states to regulate commeree, and Justice Sandra Day O' Comor's concuring opinion in Carbone explicitly noted that it is within Congress' power to permit local controls on waste flows. The Congress has proposed mumerous bills to allow controls since the mid $1990 \mathrm{~s}^{6}{ }^{6}$ and in fall, 1995 , the Sonate passed a bill amending the Solid Waste Disposal Act to permit some types of restrictions on the export and import of waste (S. 534, "The Interstate Transportation of Municipal Solid Waste Act of 1995').

\subsection{A Brief Review of the Debate. ${ }^{7}$}

Actions taken by the New Jexsey legislature in 1973 were anong the first movements to restrict waste trade. The legislature effectively banned the importation of most MSW, but operators of private landfils in New Jersey and city govermments in neighboring states challenged the action charging that it violated the Commerce Clause of the U.S.

\footnotetext{
5 See CGA Carbone v. Clarkstoun, US Sup C, No. 92-1102, 5/16/94.

6 hor example, draft bills on flow control/interstale transport have included a bill sponsored by fobert Smith (R., N.II.) and John (Chafee (R, R.I.) in the Senate, a bill sponsored by Miclatel Oxley (R, OH) and (hristopher Smith (R, N.J.) in the House of Representatives, and a bill sponsored by lited $(j p$ pon (R... Ml) in the House (see Woods, 1995).
}

7 Additional discussion is in Macauley, Salant, Walls and Fdelstein, 1993. 
Constitution. The Supreme Court eventually ruled the action impermissible (Philadelphia v. New Jersey).

During the following two decades, over 40 states sought to restrict interstate waste flows and in most cases, court procedings overtumed these actions. Most recently, and impelled largely by the costs of new landfill capacity constructed in the wake of a pereived shortage during the 1980 s, states and localities have sought new forms of flow controls. As we noted earlier, whereas previously, "flow control" had primarily referred to controls on interstate movements of waste, now such control also includes othes: restrictions on waste, including intra-state restrictions that indirectly affect interstate shipments. For example, among the most widely practiced flow control schemes are reguirements that MSW generated within local borders be managed at a designated waste processing facility. The practice is generally undertaken as a means of guaranteeing a waste stream for publicly financed disposal facilities. It is estimated that new facilitics built in the last 15 years or so have been financed with as much as $\$ 20$ billion worth of revemue bonds. In Carbone, the Supreme Court suggested that the town could ensure the long-term financial viability of the farility though fiscal measues rather than flow control. Proponents of controls have also argued that controls are a means of protecting the enviromment and achieving state and local recycling goals. In the case of Carbone, the Court said that such goals could be addressed through other, non-discriminatory satety health, and environmental segulation.

Since the Carbone decision, other fow control measues have also been invalidated by the courts. In February, 1995, the U.S. Court of Appeals for the Third Circuit foum that New Jersey's flow controls requiring disposal of non-recyclable waste at designated facilities may discrininate against interstate commere and remanded the ase back to the U.S. District Cout for the District of New Jersey. Also in February, 1995, the U.S. Court of Appeals for the Eighth Circuit invalidated a referendum bloking a lasge MSW dump in South Dakota becanse the Court said that by excluding out-of-state waste from being disposed of at the site, it discriminated against interstate commere. ${ }^{10}$

Since 1989, Congress has drafted mumerous proposals to permit flow control, including attempts to do so by amending the Resources Conservation and Recovery Act or the Solid Waste Disposal Act. Following the 1994 Carbone decision, Congress moved cuickly to advance various legislative proposals. Supporters argued, among other reasons, that waste flow control is properly the prerogative of local govermment, not federal authorities. Opponents claimed that such control is "anti-business" and imposes an "unfunded mandate" in the form of the higher disposal and waste processing costs that will be fored on municipal budgets.

In the fall, 1995, the Senate passed S. 534, "The Interstate Transportation of Municipal Solid Waste Act of 1995 " amending the Solid Waste Disposal Act. Titles I and

\footnotetext{
8 For discussion, see, for example, Woods, 1995.

9 See "New Jersey's How Control Regulations Unduly Discriminate, Rederal Court Rules;" Bnomon. ment Reporter, 24 Rebruary 1995, p. 2032.

10) See "Teferendum on "Mega-Garbage Dump" 'Thown Out for Discriminating Against Jnterstates Commones" thutronment Reporter, 10 february 1995, p. 1907.
} 
II of the bill affect waste flows. Title I of the bill grants state governors the authority to restrict ont-of-state MSW imports to $95 \%$ of their levels in 1993 and to increasingly smallex perentages over time (ending with calendar year 2003 and each succeding year. when the limit is to be $65 \%$ of the amount exported in 1993), provided imports exceded 750,000 tons per year in 1993. Title I also restricts the amount of waste that exporting states may ship to any one state. The restriction is the greater of 1,400,000 tons or $90 \%$ of the amount exported to the state in 1993 and increasingly smaller amounts over time (ending with calendas year 2002 and succeding yeas, when the limit is 550,000 tons). An exception to this export restriction is if landfills or incinerators in the importing state are authorized to receive out-of-state waste or have agreements with the host. community that permit such imports. A third provision in the title permits importing states to collect a "cost recovery charge" not to exced $\$ 1$ per ton, for the processing (a) disposal of out-of-state waste.

Title II of the bill permits junisdictions to control waste flows by reguiring that they be handled (for recycling, transfer, processing, or other management) at specific waste facilities, although generally only if such controls had been operating prior to May 15. 1994 (the date of the Carbone decision). In most provisions of this Tites flow controls may continue only antil the end of the remaining life of contrasts between the political subdivision and its contrators.

\section{Overview of the Model}

We tum now to the model we use to assess empirically the consequeness of these prom posed restrictions. Since estimates of parameters associated with the landfill matset differ widely, wo have made the model as flexible as possible and report a variety of sensitivity tests of our empirical assumptions.

A "contral planning" model such as ours can serve as a benchmark to assess the performance of the landfill market. Such a benchmask can suggest the magnitude of surplus losses attributable to the imposition of regulations or the exercise of market power. " Moreover, the allocation which achieves the maximum surphs often provides a useful guide to the kinds of reallocations which would improve the functioning of the private maket. The computerized model we have developed is intended to provide quantitative estimates of the aggregate social sumplus which potentiatly an be generated by the solid-waste industry. The model determines how the capacities of landfills located in different states in the U.S. should be drawn down or expanded over time, and which populations centers these landfills in conjunetion with spatially distributed incinerators should serve. We then use the model to calculate by how much aggregate surplus would decline with the imposition of a variety of political constraints, such as fow controls permitted by the Congress. In addition, we can quantify the distribution of these changes in surplus across states or other geographical regions.

\subsection{Nonspatial Extensions of Hotelling's Model of Depletable Resources}

II Nordhans (1973), for example, used such a model to assess the distortions in the world energy market attributable to OPlSC's exercise of market power. 
The lineage of our work can be traced to Hotelling's (1931) model of depletable resources. ${ }^{12}$ Several authors have noted the similarity between solid waste disposal problems and the depletable resource problem first studied by Hotelling, including Dunbar and Berkman (1991); Chang and Schuler (1990); and Ready and Ready (1995).

Dunbar and Berkman discuss tipping fees, focusing in part on why they may be too low if they fail to incorporate the cost of depleting the landfill over time. Chang and Schuler develop a conceptual model of landfill use over time, also focusing on optimal tipping fees. Ready and Ready model landfills as depletable resources and focus on the optimal tipping fee and its relationship to the timing of investment in other waste reduction technologies.

\section{Spatial Aspects of the Landfill Problem.}

An important aspect of the solid waste industry in the U.S. is that landfills in some parts of the country are being called upon to serve the needs of "consumers" in other parts of the country. Moreover, regulations are being introduced to limit waste shipments. Similar regulations are being introduced within other countries and between different comintics.

Until vory recenty fow artioles in the Hotelling literature addressed spatial aspects of resome extaction. To our knowledge there have been thee key papers introducing a spatial olenent: Laffont and Moreaux (1984), Kolstad (1994), and Gandot, Morcaux, and Salant (1997). Although only the last of these applies its results to landfills, we will interpuet each in terms of this application.

Laffont and Moreax (1984) study resouce extaction in a competitive model with one city at the end of a line segment and multiple landfills along the line segment. Without its complications, Laffont-Moleaux's analysis is just like Herfindahl's problen of extraction at least discounted cost where there exist mines with different constant marginal costs of extraction. ${ }^{13}$ Herfindahl showed it is always optimal to exhanst a lower: cost pool before beginning to extract from the next higher cost pool. Tf the transport cost of shipping one unit is higher for more distant resource pools, Iferfindahl's nonspatial result can be given the following spatial reinterpretation: it is socially optimal to draw down the closest pool first and then the next closest... It should be noted that this reinterpretation of Herfindalal is equally valid if the resource pools were not located on a line segment but anywhere around the one city. ${ }^{14}$

12 For an extensive bibliograplyy and an up-to-date, nontedmical introduction to the Hotelling literahure see Salant, 1995 .

1:3 In fact. laffont-Moreanx applied their model to the extantion of gavel from a contimum of sites ontside of Bordean and its shipment to Bordeanx where it is used to make concrete. Complications arise because of the contimum assumption and the fact that the land can be used as vineyards before the gravel is extracted but not afterward.

14 Weitman (1976) has extended Herfndahl's analysis to cases where the marginal cost of extraction at any landfill depends in an arbitrasy specified way on the anomt of space extatated there so far. This permits the solution of social plaming problems where spatially located landfils serving a singte city have substantial opening and closing costs. Roberts and Weitzman (1980) show that this earlior amalysis is a special case of what is now known in the statistics and operations research literatures as a "Gibins index" solution to a multi-am bandit problem. Such problems can always be fomulated 
Kolstad (1994) considered the case of multiple cities on a line segment which use space extracted from two landfills, one located at each end of the segment. Since there are two landfills, there are two initial title prices one for title to a unit of unused space in the left-hand landfill and one for title to a unit of unused space in the right-hand landfill. For familiar reasons, each title price starts at a different level but rises at the rate of interest. As usual, the initial levels of these two title prices are set so that the usage of space in each fill adds up over time to their respective capacities.

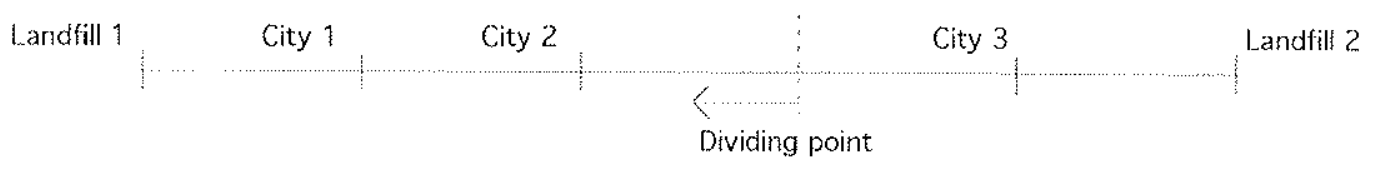

Fig. 2. Kolstad's spatial configuration: two landfills.

Kolstad notes that at any date t, there is some location between the two landfills with the property that the supply price of the left-hand fill (the cost of purchasing at time t title to a unit of the left-hand resome phes the cost of shipping it to the location in guestion) equals the supply price of the right-hand fill. Call this location the "dividing point," All cities to the left of the dividing point find purchase from the left-hand fill to be preferable while all cities to its right purchase from the right-hand fill. Over time, the dividing line changes position. Figure 2 depicts a situation in which two landfills servo 3 cities. In the period depicted, City 1 and City 2 patronize Landill I while City 3 patronizes Landfill 2. As time passes however, the "dividing point" moves to the left and City 2 (and later City 1) will switch to patronizing Landfill 2.

Gandet. Moreaux, and Salant (1997) generalize Kolstad's analysis. In their model, $I$ landfills can be located anywhere (not necessarily on a line segment), I cities (represented by demand curves) can be located anywhere, and the backstop incinerators can be located anywhere.

Gaudet, Moreaux and Salant (herafter GMS) then detemine the solution to the plaming problem (or: equivalently, the solution to the competitive equilibrium). In thesir model, titile to one unit of resource in pool $i$ has price $\lambda_{i}$. For such a title to be held, its price must rise by the rate of interest. Consider city $j$. That city could be served by any of the I landfills and, therefore, faces I supply prices. The supply price from landfill $i$ is equal to the full marginal cost of shipping another unit of "landfill space" to city $j$ the sum of the price of title to the space and the cost of shipping from landfill $i$ to city $j$ (if there is more than one way of shipping, the cheapest of the ways). City $f$ buys from the facility with the cheapest supply price. A similar story applies to each of the $J$ cities. Ultimately, the initial prices of titles to one unit of space in each of the $I$ fills is determined by the computer algorithm so that cumulative space used in

instoad as straightforward dymanic programing problems. But the crucial advantage of the (Xituinsindex approach is that it permits solution of problems which would easily rum aground on the "curse of dimensionality" if analyzed via dynamic programming. A Gitins-index apporach camnot be used to solve our problem, however. For the Gitins approach to yeld the optimal solution, only one landill can be ned at a time or, alternatively, it must be optimal to dedicate a distinet set of landfils fo each city. Such an approach may be wseful, bowever, in approximating the optimal program or, at least, in bounding ifs value when setup costs must be incurred to open a landfill. 


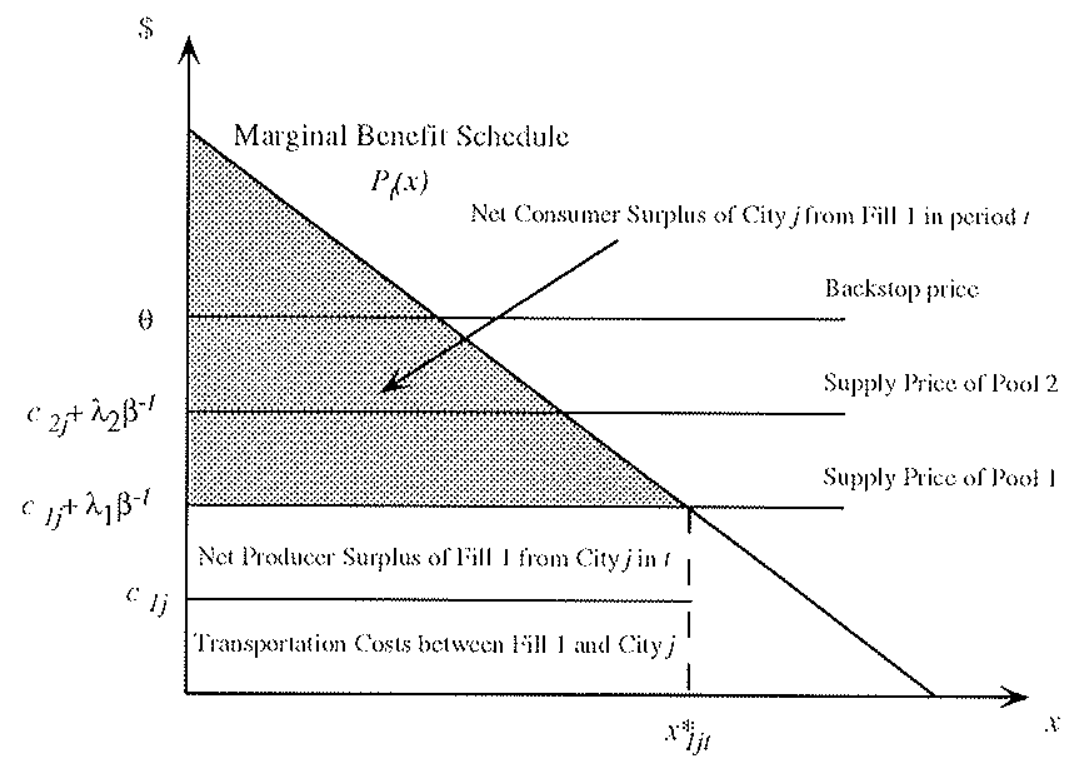

Fig. 3. GMS Model in to with 2 Landfills and 1. Incinerator avalable to City $j$

every landfill eguals its initial capacity.

Figure 3 depicts the three best choices facing city $f$ at time $t$ : the supply price of fill 1 is smaller than the supply price of fill 2 , which in turn is smaller than the supply price of the local incinerator. City if would ship all of its waste to fill 1. The supply prices of the oflex $I-3$ sources are not depicted. The price paid by city in period $t$ is the smallest of the supply prices fill 1 's supply price. We decompose that supply price into its transportation cost component $\left(c_{1 j}\right)$ and the "tip fee." Since there are no flow constraints on waste deposited by city $f$ in fill 1 , its tip fee is simply $\lambda_{1} \beta^{-l}$. All cities of origin not subject to ftow controls would pay this same tip fee at fill 1. The shaded areas correspond to net consumer surplus at city $j$ and that portion of net producer surplus generated from fill l's commerce with city $j$ (reveme net of transport: costs from transactions with city j).

We have appended to the GMS model source-specific flow constraints. If a flow control restricted what city $j$ could ship to fill 1 , it might be induced to ship to fill 2 at the same time. Figure 4 depicts the choices facing city $j$ at a given date $t$ if it is constrained from shipping more than $\bar{x}_{1 j t}$ to fill 1 . The city ships as much as it is allowed $\left(\bar{x}_{1 j t}\right)$ to fill 1 and the remainder $\left(x_{2 j t}\right)$ to fill 2 . City $j$ pays $c_{2 j}+\lambda_{2} \beta^{-t}$ per unit shiped to fill 2. Wo assume that city $j$ pays the same price to ship to fill 1 and fill 2. This would be twue as long as permits allowing city $j$ to ship a unit of waste to fill 1 are tradeable. As before the tip fee is the excess of what city $j$ pays over the transport cost since that is what city $j$ would have to pay to dispose of waste trucked to fill 1. In the presence of flow controls, the final price paid by city $j$ inchudes not merely the price of title to the unit of space depleted but also the price of a permit to ship a unit of waste from city $j$ to fill 1.

Two related points deserve emphasis. First, if fill 1 also accets waste in the same period from a city which is not subject to flow controls then that city will pay a smaller offective tipping fee. This follows since that city purchases title to the space if depletes 


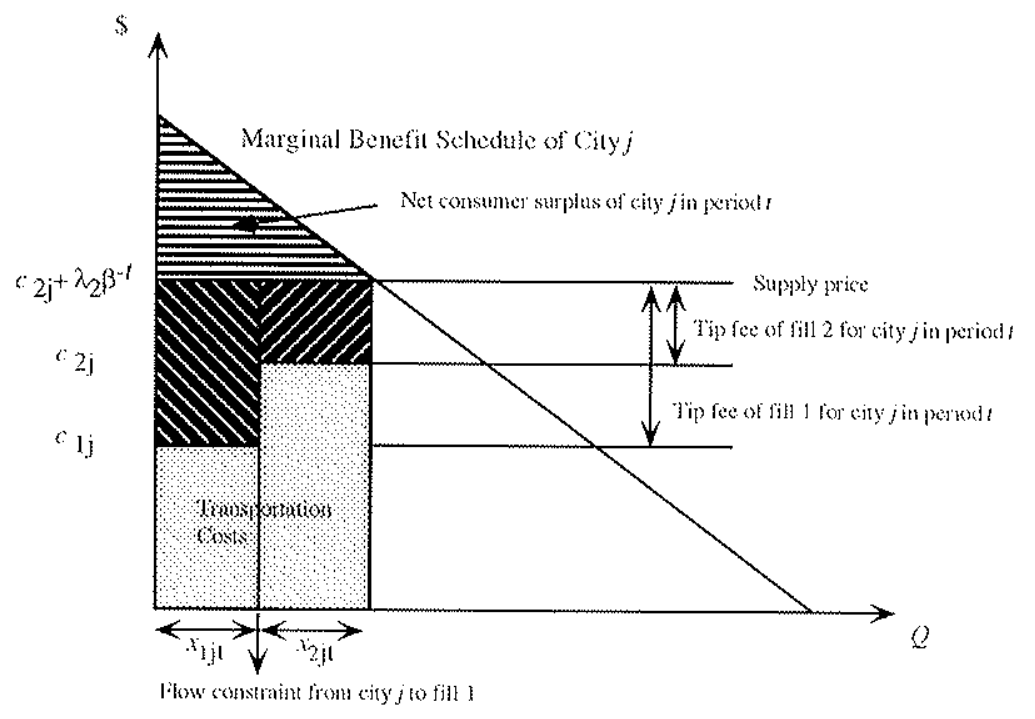

Fig. 4. CMS: City jat twith 2 fills and flow controls.

at the same price as city $j$ but does not have to purchase a permit to use the fill. This difference in the tip foes charged at fill 1 does not reffect price discrimination against city $i$ but merely the presence of binding source-specific flow controls in a competitive seting. Different citics shipping to the same fill and each sulject to a separate sonresperific: flow control would each pay a different permit price and hence would each pay a different effective tip foe to use fill 1 . all highes than the tip fee faced by an unconstrained dity. On the other hand, if a set of cities were collectively constrained to ship no more than a certain amount to fill 1 , then each would have to purchase the same permit and would therefore pay the same tip fee once again higher than what an unconstrained city would have to pay. Second, until a flow control binds, the tip fee grows at the rate of interest. When the control binds, however, the tip fee grows by a larger amount since the between-period increase in the fee reffects not merely the capital gain on the title price but also the increase in the cost of the permits to use fill 1. Since the sulssequent change in the permit price an be positive or negative the tip fees paid by cities constrained by flow controls can grow slower or faster than the rate of interest.

Figure 4 depicts the two tip fees facing city $j$. Shaded areas correspond to net consumer surplus at city $j$ and that portion of net producer surplus generated from fill 1 and fill 2's commerce with city $\%$. Another city, which could ship to either fill 1 or fill 2 with no flow constraints, would pay the same title price at either fill as city $j$ in time t and hence the same tip fee at fill 2. However, the effective tip fee at fill 1 for that: unconstrained city would be smaller than city $j$ 's since city $j$ is sulject to flow control and must purchase a permit to use fill 1.

\subsection{The Model}

Our model appends to the GMS model political constraints relevant to our policy anal- 
ysis and then mumerically solves for the surplusmaximizing program. Our notation is summarized in the following table:

\section{Exogenous Inputs}

$\beta$ Discount factor.

I Number of landfils (sites existing at the outset or (reated subsequently).

J Number of waste-generating centers (cities).

$c_{i j} \quad$ Unit transportation cost from city $j$ to landfill $i$.

$\bar{s}_{i} \quad$ Initial rapacity of landfill $i$.

$\gamma$ Rate of incease of marginal cost in handling another unit of waste at any landfill. ${ }^{15}$

$\theta \quad$ Unit cost of the backstop technology.

$U_{y l}(Q)$ City f's utility function for disposing of $Q$ units of waste at $t$.

$P_{y l}(Q) \quad$ City j's inverse demand for waste disposal. $Q ; P_{j l}(Q)=U_{j l}^{\prime}(Q)$ at timo $t$.

$D_{j l}(P) \quad$ City $j$ 's demand for waste disposal at time $t$ at price $P ; D_{j l}(P)=P_{j l}^{-1}(Q)$.

$\ddot{x}_{i j}$ Maximum amount of waste that could be shipped from city $j$ to landfill $i$ at tine: $t$.

fu. Maximum amount of waste that could be shipped to landfill if from all cities at time $t$.

Tije An upper bound to waste shipped from city $j$ to landfill $i$ at time $t\left(x_{i j}\right.$ defined below) if there are flow constraints.

\section{Indices}

i. Landfill index; $i \in\{1,2, \ldots, I\}$.

$t$ Time index; $t \in\{1,2, \ldots, T\}$.

j City index: $j \in\{1,2, \ldots, J\}$.

$S_{k} \quad$ Set of indices of landfills (or cities) belonging to the same federal state as landfill (or city) $k$.

\section{Endogenous Outputs}

$x_{y,}$ Amount of waste shipped from city $j$ to landfill $i$ at time $t$.

$x \cdot$ Total amount of waste shipped by city $j$ to all landfills at time $t ; x_{\bullet j} \equiv$ $\sum_{i} x_{i j l}$

$x_{\bullet}$ Total amount of waste shipped to landfill $i$ from all cities at time $t ; x_{\bullet \bullet}=$ $\sum_{j} x_{i j l}$

$x_{\text {. }}$ Total cumulative amount of waste shipped to landfill $i$ from all cities; $x_{\mathbf{}_{\bullet}}=$ $\sum_{t} \sum_{j} x_{i j t}$

15 This is a negligible constant introduced to elminate indeteminacies which were tripping up) the algeritim. 
Cijl Exports of waste at time $t$ from the state where city $j$ belongs to the state where landfill $i$ is located; $x_{i j t}=\sum_{j \in S_{j}} \sum_{i \in S_{i}} x_{i j l}$.

$m_{i t}$ Imports of waste at time $t$ into the state where landfill $i$ is located; mit = $\sum_{j \notin S_{i}} x_{i j t}$.

$b_{j l}$ Amount of waste of city $j$ handled by the backstop technology at time $t$.

lit. Shadow price associated with $\tilde{f}_{i t}$.

H.je Shadow price associated with $\ddot{x}_{i j t}$.

$\lambda_{i} \quad$ Shadow price associated with $\bar{s}_{i}$.

The planner's problem is given by:

$$
\begin{aligned}
\max _{m_{i j l}, b_{j t}} & \sum_{j} \sum_{t} \beta^{l}\left\{U_{j l}\left(x_{\bullet j t}+b_{j l}\right)-\theta b_{j l}-\sum_{i}\left(c_{i j} x_{i j l}+\frac{\gamma}{2} x_{i j l}^{2}\right)\right\} \\
\text { s.t. } \quad x_{i j t} \leq \bar{x}_{i j l} & \\
& x_{i \bullet t} \leq \bar{f}_{i t} \\
& x_{i \bullet \bullet} \leq \bar{s}_{i} \\
& x_{i j l} \geq 0, b_{j l} \geq 0
\end{aligned}
$$

The GMS model would consist of the objective function (1), the reserve costraints (4), and the nomegativity constraints (5). To these we add the following political constraints in varions simulations. City-landfill political fow constraints are captured by (2). They limit the amome that city $j$ can ship to landfill $i$ at each $t$. Since physical acess to the landfill or agrements with the surrounding community frecuenty limit the mumber. of tucks which can come and go from a landfill in the same day, the maximization is constrained by limits on the daily operating capacity of the disposal facilitics captures these physical landfill fow constraints.

The Lagrangean of the constrained problem is given by:

$$
\begin{aligned}
\mathcal{L}= & \sum_{j} \sum_{l} \beta^{t}\left\{U_{j t}\left(x_{\bullet j t}+b_{j l}\right) \cdots \theta b_{j t}-\sum_{i}\left(c_{i j} x_{i j l}+\frac{\gamma}{2} x_{i j l}^{2}\right)\right\} \\
& +\sum_{i} \sum_{j} \sum_{i} \mu_{i j l}\left(\bar{x}_{i j t}-x_{i j t}\right) \\
& +\sum_{i} \sum_{l} \eta_{i t}\left(\bar{f}_{i t}-x_{i \bullet l}\right) \\
& +\sum_{i} \lambda_{i}\left(\bar{s}_{i}-x_{i \bullet \bullet}\right) .
\end{aligned}
$$

The first-order (onditions are:

$$
\begin{gathered}
\frac{\partial \mathcal{L}}{\partial x_{i j l}} \leq 0 \rightarrow \quad P_{j l}\left(b_{j t}^{*}+x_{\bullet j t}^{*}\right) \leq c_{i j}+\gamma x_{i j t}^{*}+\left(\lambda_{i}^{*}+\mu_{i j l}^{*}+\eta_{i t}^{*}\right) \beta^{-l} \\
\frac{\partial \mathcal{L}}{\partial x_{i j t}} x_{i j t}^{*}=0 \Rightarrow \quad\left\{\left(P_{j t}\left(b_{j t}^{*}+x_{\bullet j t}^{*}\right)-c_{i j}-\gamma x_{i j t}^{*}-\left(\lambda_{i}^{*}+\mu_{i j t}^{*}+\eta_{i t}^{*}\right) \beta^{-\ell}\right\} x_{i j t}^{*}=0\right.
\end{gathered}
$$




$$
\begin{aligned}
& \frac{\partial \mathcal{L}}{\partial b_{j t}} \leq 0 \Rightarrow \quad P_{j t}\left(b_{j t}^{*}+x_{\bullet j t}^{*}\right) \leq \theta \\
& \frac{\partial \mathcal{L}}{\partial b_{j l}} b_{j l}^{*}=0 \Rightarrow \quad\left\{P_{j l}\left(b_{j l}^{*}+x_{\bullet j l}^{*}\right) \cdots \theta\right\} b_{j l}^{*}=0 \\
& \frac{\partial \mathcal{L}}{\partial \mu_{i, j t}} \geq 0 \Rightarrow \quad \bar{x}_{i j l} \geq x_{i j t}^{*} \\
& \frac{\partial \mathcal{L}}{\partial \mu_{i, j t}} \mu_{i j t}^{*}=0 \Rightarrow \quad\left\{\bar{x}_{i j t}-x_{i, j t}^{*}\right\} \mu_{i, j t}^{*}=0 \\
& \frac{\partial \mathcal{L}}{\partial \eta_{i t}} \geq 0 \Rightarrow \quad \tilde{f}_{i t} \geq x_{i \bullet t}^{*} \\
& \frac{\partial \mathcal{L}}{\partial \eta_{i t}} \eta_{i t}^{*}=0 \Rightarrow \quad\left\{\vec{f}_{i t}-x_{i \bullet t}^{*}\right\} \eta_{i t}^{*}=0 \\
& \frac{\partial \mathcal{L}}{\partial \lambda_{i}} \geq 0 \Rightarrow \quad \bar{s}_{i} \geq x_{i \bullet \bullet}^{*} \\
& \frac{\partial \mathcal{L}}{\partial \lambda_{i}} \lambda_{i}^{*}=0 \Rightarrow \quad\left\{\widetilde{s}_{i}-x_{i \bullet \bullet}^{*}\right\} \lambda_{i}^{*}=0
\end{aligned}
$$

with $x_{2, t} \geq 0, b_{j, t} \geq 0, \lambda_{i} \geq 0, \eta_{i t} \geq 0$ and $\mu_{i j t} \geq 0$.

We can now daborate on our previous discussion of the "tip fee" charged city j by landfill $z$ in the presence of flow constrants. The tip fee at time $t$ is the difference betwon what city $j$ pays to dispose of its waste at landfill $i$ and the transpont cost of shipping to landill $i$. From (6), the formula for the tip fee is: $P_{j t}-c_{k t}=\gamma x_{i j t}+\left(\lambda_{i}^{*}+\mu_{i j t}^{*}+\eta_{i l}^{*}\right) \beta^{-1}$. Since $\gamma$ is virtually $\%$ ero and is introduced in the code only to facilitate computation. we ignore it henceforth. In the albsence of flow controls, $\mu_{i j t}^{*}=\eta_{i k}^{*}=0$ and the tip fee is simply the price of title to the space in landfill $i$ which will be depleted. However. if aty $j$ is constrained by political flow controls, it must purchase permits to ship to landfill $i$ and the tip fee includes the multipliers reftecting the prices of these permits. In a maket setting; the distribution of these tradeable permits would not affect the competitive equilibrium allocation or the aggregate surplus. It would, however, affect the distribution of the surplus generated. In the simulations we report, we assume that: (1) $\eta_{i t}^{*}$ is collected by landfill $i$; and (2) the multiplies associated with the regulatory comstraint: $\mu_{i j l}^{*}$ is treated as a tariff imposed on city $j$ by the state where landfill $i$ is located and it is ralculated separately.

As discussed previously, we can accomodate either the creation of space in a completely new landfill or the marginal expansion of space in an existing landfill provided that in neither case are there setup costs or other nonconvexities. In the case of new landfills, the central planner would be deciding in each period which potential landfill to develops.

The following case is trivial to imploment and illustrates the strengths and woaknesses of om: approach to capacity expansion. Suppose additional space can be created at constant marginal cost $\alpha$ but the potential cumulative expansion is limited to $\vec{A}$ units of space. This case can be implemented without change in the formulation described above. It is infeasible to use space that has not yet been created. But if expansion occurs at constant marginal cost, space will not be created until it would be used. Given this; a potential landfill can always be represented by a cost of production $a$ 
and an initial size $\ddot{A}$. By the same token, if this new landfill is located adjacent to an existing landfil, the plamer would use the new one just as if he were expanding the old landfill. To obtain the full marginal cost or supply price paid by a particular city for using an expanded landfill at date t one would add (1) the marginal cost of creating the space $(\alpha),(2)$ the price of a title to the unit of the newly-created space being depleted, and (3) the transport cost of shipping a unit of waste between that city and landfill. If the marginal cost of creating space in a particular landfill is sufficienty large, it would never be developed (implying $\lambda_{i}=0$ ). If there are potential landfills in many different: locations, the plames: would decide which ones it is optimal to develop first. More generally, the planner would be deciding when to develop potential new landfills and when to expand old ones.

The marginal cost of ereating additional space need not be constant. It could increase with the amount of space created in a period or could depend on the amount of space previously created. Such formulations are tractable provided the resulting planning problem remains concave. We defer further discussion of how one might proced in the presence of nonconvexities until the "extensions" section at the end of the paper. ${ }^{16}$

The computational problem is to find the $I \times J \times T x_{i j l}^{*} s ; J \times T b_{j l}^{*} ; s ; \quad s \times J \times T$ $\mu_{h i j l}^{*} ' s, I \times T \eta_{i l}^{*}$ 's, and $I \lambda_{i}^{*}$ 's which satisfy conditions $(6)$ (15). Given our curvature assumptions, there will be a mique solution to (6) (15) comresponding to the global (o) timmo to (1) ${ }^{1 / 7}$

\section{Data}

Before describing ous data in detail. we note several datamelated simplifications in on: simulatons. The first is that we have selocted as our geograplie region of interest the specifie portion of the waste market that accounts for the bulk of interstate shipments. This market is fourteen states in the Northeast and Midwest; although this market represents only about $36 \%$ of the total volume of waste generated nationwide, it represents $75 \%$ to $84 \%$ of the total volume of waste shipped interstate (the range reftects differonces between ostimated imports and exports; see below). Table 1 lists these states. including the levels of their exports and imports and their trading partners as reported in published survey data. We use this information to compare our simulation results for: the initial period of the operation of our model with the actual circumstances at work in the MSW market.

A second major simplification is to assume that waste is generated in one, or for:

if Problems arise if the creation of any new landfill space involves a large setup cost. Nonconvexitics canse familias problems. In the market context, competitive equilibrium nay not exist (liseher, 1995 ). The plaming problem still has a global optimm but since some nom-optinal programs also solve the first-order conditions, more cases must be examined to locate the global optimum. GMS lave considered plaming problems with setup costs when there are thee landflls and have identifed characteristics of the solution which have no counterparts in the cases previously studed in the literature. For example: with as lew as two cities, they find it is sometimes optimal to draw down a landfill part way, abandon it in favor of a newly developed landfill, and then return to it after the new one is exhalusted. In the concave problems andyzed by Herfindahl (1967), such behavior is never optimal. Indeed, it is never optimal in the one-city problem with setap costs analyzed by Weitzman (1976).

17 The fortran code used is available avalable upon request from edleyobigfoot.com. We lave also posed the problem as a mixed complementary problem in GAMS. 
Table 1. Waste Generated, Exported and Tmported, and Trading Partners, 1993

\begin{tabular}{|c|c|c|c|c|c|}
\hline & \multicolumn{3}{|c|}{ Millions of tons per year } & \multicolumn{2}{|c|}{ Shipments: } \\
\hline & Waste Generated ${ }^{a}$ & Exports & Imports & To & Erom \\
\hline New York & 25.2 & 3.9 & 0.2 & $\mathrm{PA}, \mathrm{OH}, \mathrm{H}, \mathrm{N}$ & Canada \\
\hline New Jersey & 7.3 & 1.6 & (neg.) & PA, VA, WV & NY \\
\hline Illinois & 14.7 & 1.0 & 1.0 & $\mathrm{NN}, \mathrm{OH}, \mathrm{WI}$ & $M O, I N, M$ \\
\hline Missouri & 7.5 & 1.0 & 0.03 & $1 \mathrm{H}, \mathrm{KS}$ & $(?)$ \\
\hline Pemmsylvania & 9.5 & 0.8 & 3.8 & OH, WV, H, TN & NJ, NY \\
\hline Rhode Island & 1.2 & 0.6 & - & OH, MA & - \\
\hline Ohio & 17.5 & 0.3 & 1.7 & $\mathrm{MI}, \mathrm{PA}, \mathrm{KY}$ : & $N Y, N J, P A, R$. \\
\hline Virginia & 7.6 & 0.03 & 1.5 & $\mathrm{NG}$ & \\
\hline West Virginia & 1.7 & 0.1 & 0.5 & PA,OH, KY & $P A$ \\
\hline Comnecticut & 2.3 & - & 0.8 & - & $(?)$ \\
\hline Massachusetis & 6.8 & 0.4 & 0.7 & NH & RI, NY \\
\hline Now hampshire & 1.1 & 0.03 & 0.5 & $\mathrm{MA}, \mathrm{MI}$ & $\mathrm{MA}$ \\
\hline Indianaz & 4.4 & 0.08 & 0.8 & $\mathrm{H}, \mathrm{OH}, \mathrm{KY}, \mathrm{MH}$ & $N Y, N\}, 11, P A$ \\
\hline Kansas & 2.7 & - & 0.7 & - & MO \\
\hline Jotals" & 109.5 & 9.8 & 12.2 & & \\
\hline Total as \% of US & $36 \%$ & $75 \%$ & $81 \%$ & & \\
\hline US 'lotals & 306.9 & 13 & 14.5 & & \\
\hline
\end{tabular}

Somres: Waste generated: BioCycle, 1994: Waste exported and imported: Wochathy 1995 (hee also notes therein); Shipment destimation/orgination: MeCarthy and stade datia avalable from anthors.

a the amomt of waste generated that is landitled varies widely across states: nost wasto that is exported or imported is landfilled, although there are exceptions (in Comnecticut, for example, about 1/3 of imports go to waste-to-energy facilities (see Mc(arthy for discussion)).

" Lxports and imports do not match for at least bwo roasons. One is that states in addition to those listed above export and import waste; the other is that evon in nationwide data, reported exports and imports do not match - see bottom line above (sec NoCarthy for discussion).

"Reflecting shortcomings in the available data, trading partiners do not always match (for example, N. reports receiving from NY but NY does not report slipping bo N.J).

grographically large states, two geographic locations in each state, and that all of the states landfill capacity is at this location(s). For example, for New Jersey wo assume that all of the state's waste is generated in Trenton and that New Jersey's entire landfill capacity is also located there. Table 2 lists the locations we have chosen for each state (and the acronyms we use to refer to them). We make this simplification because most of the actual data we use to benchmask our simulations are reported for an entire state: not individual localities. This assumption has a potentially important implication which we discuss bolow in describing the baseline simulation and its results. ${ }^{18}$

Our third simplification concems the inverse demand curves. Each inverse demand curve is assumed to pivot ont around its vertical intercept at $5 \%$ per year to reflect population (and income) growth. To calibrate our model we use as the initial horizontal intercept of each inverse demand curve the quantity of waste which is actually shipped

18 Where we have established two locations in a state, we have allocated total state waste goneration between the locations based on their population. We have allocated total state landfill capacity between the two locations based on data in Solid Wosle Digest giving landfill locations and capacities. 
Table 2. Locations and abbreviations used in the model

\begin{tabular}{|c|c|}
\hline NYC & New York Cicy, NY \\
\hline NYB & Buffalo, NY \\
\hline N. & Trenton, NJ \\
\hline II. & Chicago, II, \\
\hline MO & St. Louis, MO \\
\hline$P A P i$ & Pittsburgh, PA \\
\hline PAPli & Philadelphia, PA \\
\hline R.I & Providence, RI \\
\hline $\mathrm{OHCl}$ & Cleveland, OH \\
\hline $\mathrm{OHCj}$ & Cincimnati, OH \\
\hline$V A$ & Richmond, VA \\
\hline WV & Charleston, WV \\
\hline UT & Hartford, Cl \\
\hline MA & Boston, MA \\
\hline $\mathrm{NH}$ & Concord, $\mathrm{NH}$ \\
\hline $\mathrm{INI}$ & Indianapolis, IN \\
\hline $\mathrm{ING}$ & Gary, IN \\
\hline $\mathrm{KS}$ & Jopeka, KS \\
\hline
\end{tabular}

by that particular city to landfills. A common initial slope for the inverse demand oures of all cities is chosen so that the elasticities in the sinulations mat ch elasticitios discussed in the ompirical literature on the demand for waste disposal services (we discuss this literature below).

A fourth simplification concens recyching and incineration. We assume that a fixed proportion of a city's growing waste stream would be recycled independent of time or: the price of recycling or disposing of waste in alternative ways. Hence, the inverse demand curve of a city reflects a city's need to landfill or incinerate that portion of its wastes which are not recycled. In the simulations reported here, we assume away the need to dispose of ash and other residuals which in fact result when waste is incinerated. These simplifications create biases that are to some extent offeting. If recycling rates wexe to increase by more than $5 \%$ per year, we would overestimate landfilling since we have assumed that recycling grows at the same rate as the overall waste stream. On the other hand, our treatment of incineration underestimates landfilling since, contrary to om: assumptions, incinerator ash is typically landfilled. Among our sample of states, the perentage of waste landfilled ranges fiom $25 \%$ (Massachusets) to $88 \%$ (West Virginia): cleven of the states in our sample landfill $60 \%$ or more. (The national average is $71 \%$.)

19 An extension of the model conld take into accound the residuals which arise when waste is incinerated. The plamer would consider the full cost of incinerating a ton of waste at each incinerator: the sum of the cost of shipping it to that facility, the cost of using that facility, and the cost of shipping a constant fraction representing the residual from the incinerator to the cheapest landfill or "ultimate backstop" for final disposal. If the residuals from incineration are landfilled, the cost of title to the space would be taken into account. If processed by the "ultimate backstop" tho cost of doing so must be specified. It would be necessary to postulate an "ultimate backstop" since the landfills would ultimately fill up and, in the current version of the model, the siting of new landfils is not possible. 
Most of the available data that we use are quite limited for several widely recognized reasons. States have begun collecting statistics about waste generation and disposal only recently, and the types of data collected vary among states. Some jurisdictions carry out detailed surveys to determine quantities of in-state waste generation and waste imports and exports; others extrapolate using national data on waste generation per capita in their calculations. Most of our data are from publicly available surveys reported in the trade literature or state agencies. Also, most of our datia are for 1993 1994, the most recent years for: which information is available. ${ }^{20}$

There are other shortcomings in these data. For example, definitions of MSW vary anong states. Some include construction and demolition debris or municipal shdge: others do not. In addition, as noted in table 1, reported volumes of imports and exports typically do not match between any pair of states (a similar problem also arises in intermational tade statistics on imports and exports). Usually, imports reported by the receiving state exced exports reported by the shipping state. Another problem is that data on average ammal tipping fees only approximate the fees that might be charged under long-term waste management contracts and the fees charged daily in the: "spot" maket. The data on landfill capacity are also imperfect; stimates of landfill design caparity can change due to landfill expansion or closue, or changes in operating; permits, and daily operating capacity can vary for these reasons as woll as those rolated to wather or other short-nun conditions. Our sources of data and our attempts to adjust for some of their shortcomings follow below.

Demand price elasticities and demand growth over time. We specify lincar domand functions for waste collection and disposal services for each geographic state in arch time poriod using the following equation: $Q_{j l}=\left(A_{j}-B \cdot P_{j l}\right)(1+g)^{\prime}$ : where $A_{j}$ is the waste generated in tons, $B$ is a slope paraneter, and $g$ is the anmal growth ate. The subseripts $j$ and thefer respectively to the city and the time period. The price dasticity is them:

$$
\varepsilon_{j t}=-B \frac{P_{j t}}{Q_{j t}}=-\frac{A_{j}-Q_{j t}}{Q_{j t}}
$$

Demand grows over time because of growth in income and population. Estimates in.. dicate that waste generation has been growing about $5 \%$ ammally during recent years (se: BioCycle, April, 1994). ${ }^{21}$

20 Several more stringent enviromental reguations governing landill operation, mandated in subtitle 1) of the Resources Conservation and Recovery Act, were to have become effective during this period. 'The anticipated results were the closing of substandard landfils and higher operating costs at others. 'The trade press reports that indeed, substandard facilities did close, but these were largely smallapacity facilitics. 'The press reports also, lowever, that new, large municipal factlities opened to of sef the dectine in aggregate capacity. We compare ous 1993 state data with 1994 stale data from the $\Lambda$ prit 1994 and 1995 issues of Biofycle and find only small differences anong states in ow model. More recent data, when they are avalable, may shed further light on the effects of subtito b and othor changes in the disposal market.

21 If we were to assume that income grows at rate $g$ and that demand growth is due solely to income growth, then the income olasticity of demand is mity. As wo note above, however, we assume our parameter $g$ is a mix of income and population growth. Econometric estimates of income clasticities are generally small (around .05) although some estimates are as large as 2 or 4 (see discussion and referenes in lallerton and Kimmaman). 
We paranoterize equation (16) such that the price elasticity is within the range of previously reported econometric estimates of the price elasticity of demand for waste en).lection and disposal services (see Fullerton and Kimnaman, 1993; Jenkins, 1991; Wert/, 1976; Moxris and Byrd, 1990, and Skumatz and Bredkinuidge, 1990). These estimates gencrally suggest highly price-inelastic demand, on the order of -.26 to -.075 . The price clasticities in ous baseline model vary across geographic states and over time; the average across states for 1993 is --..15. As we discussed in the preceding section, the linear inverse demand curve of each city is assumed to pivot around its vertical intercept, its elasticity at any given price will not change. However, in our simulations, the price a city pays for waste disposal rises over time and, therefore, so does the elasticity of demand. Because the most recent econometric data suggest elasticities toward the less elastic range, we also test the sensitivity of the model with less elastic demand. ${ }^{22}$

Operating capacity and backstop costs. The operating capacity of landfills (tons per day) are state-wide averages reported for 1993 in various issues of Solid Waste. Digest. We multiply the daily operating capacity by 300 to convert it to an anmal measure. Incineration costs are also an imput to our simulations. We use observed incinerator tipping fees as proxies for the marginal costs of our backstop techology. We realize that estimates of capacity and incinerator tipping fees are subjoet to the problems noted canlier but we do not adjust for them. In cases where states do not have incinorators, we nsed the tipping fee at the next neasest incinerator in a noighboring state to reposent the marginal cost of the cheapest incinerator available to the city (this amount generated landfill tipping fees close to actual reported fees in om baseline model we discuss this below). We vary our assumed backstop costs in testing the? sensitivity of the model.

Transportation costs. We telephoned experts in waste hauling to obtain an estimate of transportation costs per mile per ton of waste. A consensus estimate was 11 cents. We vary this estimate between 5 cents and 11 cents in sensitivity tests. ${ }^{23}$ Wo calculate travel distances between states using Rand MeNally and American Automobile Association maps.

Discount rate. We use 5 pereent as the discount rate in our baseline model and use 10 percent in sensitivity tests.

MSW generation, percentage of waste landfilled, landfill capacity. Data on the ammal number of tons of MSW generated by state, the percentage landfilled, and state-wide landfill capacity are from an anmual nationwide survey reported in BioCycle magarine's assessment; "The State of Garbage in America." We use data from their 1994 survey, contained in the April, 1994 issue of BioCycle. Some of these data are from earlier ammal surveys, and data from a few states include a portion of industrial and construction/demolition waste in addition to conventionally defined MSW (soe

22 There is evidence that price elasticities can vary markedly among different types of waste but we do not lake that into account (for instance, some waste is more asily recyclable; sec fullerton and Kinmanan, and Signan for discussion of elasticity differences).

23 We spoke with representatives of two long-haul trucking firms and one railroad (information avajable upon repuest). Becanse most waste is moved by truck (only $2 \%$ is twansported by rajl (see Woods. 1997)). Wo use estimates of trucking costs. 
BioCycle, April, 1994 for details). We did not attempt to adjust the data for these inconsistencies. In addition, we also used the reported data on landfill capacity remaining in the state although, as noted above, landfill capacities can be altered though expansion or changes in permitting. We report in our results section the effect of allowing marginal landfill expansion to occur in our simulation.

Interstate waste flows. We do not use this information in our model but we do use it in evaluating our model's results. Estimates of state waste imports and exports during 1993 are from a survey by the Congressional Research Service (see MeCarthy, 1995 and, where available, additional data we obtained from state agencies that identify waste flows among all trading partners (these data were available from Pennylvania, Illinois, and Indiana). As noted earliex, because import and export amounts generally do not match among partners, we follow the practice of studies of international trade and use import data. Our presumption is that importing states have an incentive to collect more accurate information about waste imports because of eitizen opposition to these imports. (In the case of intermational trade statistics, import data are usually considered more reliable because trade managenent, such as the imposition of import tarifts and glotias, requires detailed information on quantities of imports.)

\section{Results of the Baseline Simulation}

In this section we discuss results of our baseline simulation. We describe the prices and allocations in the first yeas (1993) and compare them with the "real world" data. We also discuss sensitivity tests of the baseline to changes in the values of tis exogenenus paraneters inchaling demand elasticity, tansportation costs, the discount rate and the costs of backstop technology (incineration). We also discuss results of permiting landfills to expand by a small amount. Table 3 lists the parameters we use for the basdine nodel.

Table 4 summarizes results of the baseline and, for comparison, actual data on tip foes and the value and patterns of interstate flows. The parameters we assume in the baseline generate estimated tip fees and an aggregate volume of interstate shipments that are consistent with avalable data. The unweighted average of our estimated tip fees is $\$ 39$ compared with $\$ 41$, the average in the actual data. Estimated shipments total 10.2 million tons per year, in line with actual estimates of 9.8 to 12.2 million tons per year (representing reported exports and imports, respectively). The pattin of trading partners and the relative volumes of waste traded among partners is also consistent with available information. However, the model yields fewer trading partiners, particularly mong states that trade in small volumes, than the real-world information indicates.

The model may predict fewer trading partners because of our restrictive assumption (which we made to reduce data collection requirements) about the location of wasto generation and disposal. Our assumption of co-located waste generation and landfill capacity within a state means that for each state, the distance between the location of generation of waste in the state and that state's own landfill is zero. This assumption makes using a state's own landfill more attactive than interstate trade. The model underestimates interstate shipments:

- among states that are large or whose city/landfill sites are in the interior of the state 
Table 3. Baseline parameters

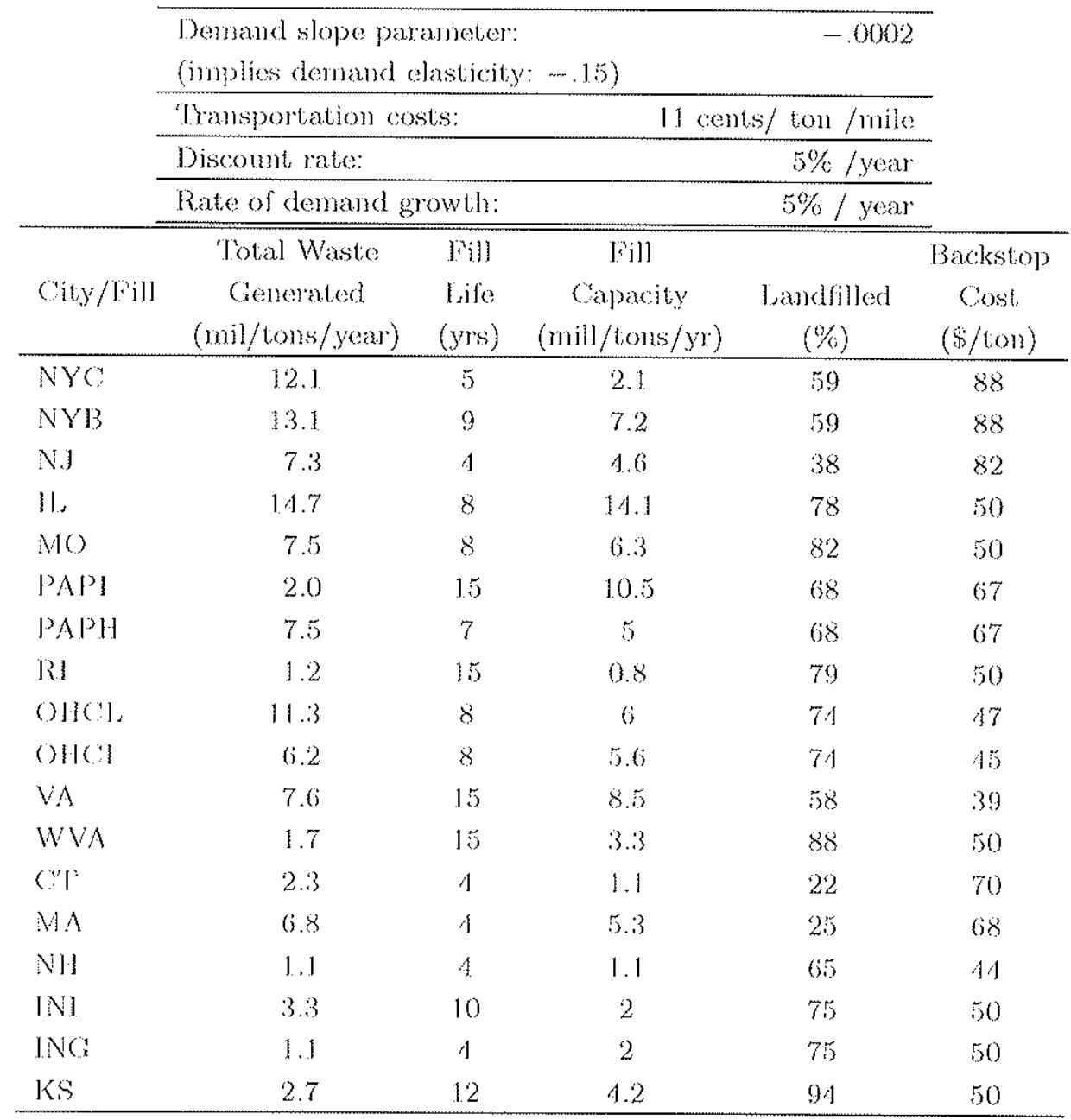

rather than on its borders (our use of two locations in large states alleviates this problem somewhat);

- among states where there are many landfill locations throughout the state;

- and anong states where landfill capacity is not neas the large population centers from which waste generation is assumed to originate.

Our model also estimates the discounted present value of economic surplus, reported in table 5. (f total surplus of $\$ 1,658$ billion, consumer surphus represents $\$ 1,629$ billion or $98 \%$. Total discounted surplus is about $\$ 7,988$ per person for the state populations represented in the model. The per capita amounts vary widely among states, however, ranging from $\$ 34$ in $C T$ to $\$ 20,088$ in OHCl. They are large among some waste importing sites (such as OHCl, IL, NYB, and MO).

Figure 5 illustrates the time path of real tip fees from 1993 to 2013 (by 2013, all but two sites are using their bakstop technologies). The unweighted average fee for: all citis increases about $1.63 \%$. The largest increases are in the Northeast. Note that whereas it might be expected that the average fee should rise by the rate of interest, 
Table 4. Baseline: Simulated Results and Actual Values for 1993

\begin{tabular}{|c|c|c|c|c|c|}
\hline & \multicolumn{2}{|c|}{ Tip ree (\$/lon) } & \multicolumn{2}{|c|}{ Interstate Shipments } & Shipments \\
\hline & Actual & Simulated & Actual $^{b}$ & Simulated ${ }^{b}$ & To (From $)^{d}$ \\
\hline NYC: & 62.75 & 62.52 & 3.9 & 4.8 & NJ, PAPl OH, VA, WV, CT, MA, IN \\
\hline$N Y B$ & 62.75 & 52.93 & & 0.3 & $P \wedge P i$ \\
\hline NJ & 77.14 & 55.67 & 1.6 & 2.5 & VA $(\mathrm{NYO}), \mathrm{PA}, \mathrm{WV}$ \\
\hline 11 & 25.17 & 33.29 & $1.0(1.0)$ & & $\mathrm{IN}, \mathrm{WI}$ \\
\hline MO & 26.48 & 33.82 & 1 & & $\mathrm{IL}, \mathrm{KS}$ \\
\hline$P \wedge \mathrm{Pi}^{\prime}$ & 36.00 & 27.5 .3 & $.8(3.9)$ & & $(\mathrm{NYB}, \mathrm{OHCl}) \mathrm{WV}, \mathrm{NJ}$ \\
\hline$P \mathrm{PPh}$ & 55.00 & 51.05 & & & $(\mathrm{NYC})$ \\
\hline R! & 18.18 & 44.54 & 0.5 & & $(\mathrm{C}), \mathrm{MA}$ \\
\hline Oमल० & 33.29 & 41.33 & $.3(1.7)$ & 2.2 & PAPI (INI) MI, KY, WV, NY, NJ \\
\hline $\mathrm{OHCi}$ & 24.00 & 30.34 & & & \\
\hline $\mathrm{VA}$ & 33.75 & 25.49 & $(1.5)$ & & $(\mathrm{NI}), \mathrm{NC}$ \\
\hline WVA & 29.94 & 17.49 & $.1(.5)$ & & $\mathrm{KY}, \mathrm{MD}, \mathrm{OH}, \mathrm{PA}$ \\
\hline TT & 65.26 & 50.03 & & 0.1 & MA \\
\hline MA & 55.97 & 42.38 & $.4(.7)$ & & NH, RI, NY \\
\hline $\mathrm{NH}$ & 41.36 & 36.61 & 0.03 & & MA, ME \\
\hline $\mathrm{INI}$ & 22.81 & 42.26 & $.08(.8)$ & 0.3 & $\mathrm{OHC}, \mathrm{N}_{,}, \mathrm{KY}, \mathrm{Mr}$ \\
\hline ING: & 22.81 & 333.22 & & & \\
\hline KS & $10.32^{a}$ & 24.87 & $(0.7)$ & & MO \\
\hline
\end{tabular}

\begin{tabular}{|c|c|c|c|c|c|}
\hline & \multicolumn{2}{|c|}{ Average 'lip liee } & \multicolumn{2}{|c|}{ Total l'iade Volume } & \\
\hline & 40.71 & 39.14 & $9.8 \cdot 12.2$ & 10.2 & \\
\hline
\end{tabular}

Semer: Actual tip fee fon landills: Solid Waste Digest, varions issines.

"Average may be larger; Biocycle(1994) reports $\$ 25$.

${ }^{b}$ In milloms of tons per year; numbers in parentheses are imports; estmatod are either.

CStafes divided in model; see text.

"Boldaces are trading patners reported in MoCathy (1995) but not predicted by the simulation.

Insert figure around here

Fig. 5. Baseline: Tine Path of Tip Fees (unweighted avelage).

the tip fee is in fact the sum of shadow values on a unit of landfill capacity as well as on the operating capacity of the landfill. Thus, for instance, in the case of MO, the constraint on operating capacity does not bind in the first year of operation but does bind by the fifth year; leading to a $46 \%$ increase in the predicted tip fee. In the case of NYB, however, the operating constraint binds in the first year but not by the fifth yeas, leading to an increase of just $11 \%$ in the tip fee.

\section{Insert, figure around here}

Fig. 6. Baseline: Total Volume and Number of Trades.

Figure 6 illustrates the behavion of these flows over time by indicating the number of trading partiners each year and the aggregate volume of interstate shipments. Waste 
traded as a perent of waste generated increases from $15 \%$ in 1993 to $33 \%$ in 1998 as states exhaust in-state landfill capacity. By 1998, these interstate flows occur among 11 different pairs of trading partiners (e.g., NY - PA, NJ -.. VA). After 1998, more and more states begin to use their backstop technology and the volume and number of interstate trades begin to decline. By 2009, interstate flows have reached a trickle. It is not dear from debate on interstate waste whether it is the number or volune of shipments that is of most concem in public pereption. Large numbers of small shipments may generate roadway wear and tear or congestion, say, and large shipments "use up" communities" landfill space.

Table 5. Baseline Model: Discounted Producer and Consumer Surplus

\begin{tabular}{|c|c|c|c|c|}
\hline & \multicolumn{3}{|c|}{ Billions of 1993 dollars } & Dollars \\
\hline State/ & Producer & Consumer & 'lotal & Iotal Surplus \\
\hline I.sandfill & Surplus & Surplus & Surplus & per capita \\
\hline NYC & 0.649 & 180.364 & 181.013 & 7.153 \\
\hline$N Y B$ & 3.087 & 214.825 & 217.912 & 14,099 \\
\hline $\mathrm{NJ}$ & 1.025 & 22.861 & $2: 3.886$ & 1,352 \\
\hline II. & 3.812 & 503.999 & 507.811 & 19,165 \\
\hline MO & 1.930 & $1: 39.428$ & 141.358 & 12,804 \\
\hline$P \wedge P i$ & $4.67^{\circ}$ & 4.612 & 9.284 & 1,051 \\
\hline$P \wedge P h$ & 1.796 & 91.060 & 92.850 & 5.257 \\
\hline RII & 0.511 & 1.956 & 2.467 & 1,117 \\
\hline OHCl & 1.832 & 264.298 & 266.130 & 20,088 \\
\hline OHCI & 1.403 & 76.399 & 77.802 & 7,047 \\
\hline$\vee \wedge$ & 3.700 & 71.157 & 74.857 & 5,650 \\
\hline WV & $0.9: 31$ & 6.699 & 7.6333 & 1,728 \\
\hline ("I? & 0.221 & 0.115 & 0.3336 & 51 \\
\hline$M A$ & 0.899 & $7.60: 3$ & 8.502 & 642 \\
\hline $\mathrm{NH}$ & 0.161 & 0.989 & 1.150 & 521 \\
\hline IN] & 0.773 & 19.844 & 20.617 & 3,112 \\
\hline $1 \mathrm{NQ}$ & 0.266 & 1.373 & 1.639 & 247 \\
\hline$K S$ & 1.226 & 21.459 & 22.685 & 3,125 \\
\hline 'lotals & 28.897 & $1,629.041$ & $1,657.938$ & $5,82: 3$ \\
\hline
\end{tabular}

Trasert figure around here

Fig. 7. Landfill Expansion at \$5/Ton.

Landfill expansion. Expanding a landfill is usually quite political controversial within the community adjacent to the fill, but municipal and state authorities sometimes anend landfill operating permits to allow some expansion wasually on the order of a few percent of capacity. Accordingly, we permitted our baseline model to expand landfill caparity endogenously, at $2 \%$ a year for four years, under three scenarios: expansion at $\$ 5$, $\$ 10$, and $\$ 15$ per ton. We find that the volume of waste traded and the mumber of pairs of states that trade waste is virtually unchanged. Not all landfills expand; expansion 
largely takes place in the Midwest. Figure 7 illustrates the results for expansion at $\$ 5$ per ton.

\section{Sensitivity of the Baseline Simulation}

In this section, we discuss the sensitivity of the baseline model to changes in several exogenous parameters: price elasticity of demand, the discount rate, transportation costs, and the cost of the backstop technology. When price elasticity changes, what are the effects on the volume traded and the pattern of trade? When transportation costs decline, does trade with, say, the Midwest increase? If so, anong which trading partners? When the cost of the backstop technology increases, do states use more of their: own landfill capacity or do they increase exports? If they increase exports, with whom do they trade?

Table 6. Results of Sensitivity Tests

Direction of change compared with baseline.

\begin{tabular}{|c|c|c|c|c|c|}
\hline \multicolumn{6}{|c|}{ Reducing denand elasticity to -... 01 (average across states) } \\
\hline & \multirow{2}{*}{$\begin{array}{l}\text { Average } \\
\text { 'lip lee }\end{array}$} & \multirow{2}{*}{$\begin{array}{c}\text { Volume 'luaded } \\
\text { (\%'lotal) }\end{array}$} & \multicolumn{3}{|c|}{ Discounted Present Value of Surphus, 1993.2013} \\
\hline & & & Producers & Consimers & 'T'otal \\
\hline 1993 & 1 & 丹ी & \multirow[b]{2}{*}{1} & \multirow[b]{2}{*}{ fll } & \multirow[b]{2}{*}{ nी } \\
\hline 2013 & 1 & $1^{a}$ & & & \\
\hline \multicolumn{6}{|c|}{ Inereasing the disconnt wate to $10 \%$} \\
\hline & \multirow{2}{*}{$\begin{array}{l}\text { Average } \\
\text { 'lip lis: }\end{array}$} & \multirow{2}{*}{$\begin{array}{c}\text { Volmo 'laded } \\
\text { (\%: lolal) }\end{array}$} & \multicolumn{3}{|c|}{ Discombed Present Vahne of Smplus, 19932013} \\
\hline & & & Prodikors & Comsimers & Total \\
\hline 19933 & 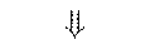 & $\Uparrow$ & & & \\
\hline 2013 & 隹 & $\sim$ & $\Downarrow$ & $\Downarrow \Downarrow$ & H \\
\hline \multicolumn{6}{|c|}{ Reducing Thansportation Costs to 5 $/ /$ ton $/$ mile } \\
\hline & \multirow{2}{*}{$\begin{array}{l}\text { Average } \\
\text { 'lip lies: }\end{array}$} & \multirow{2}{*}{$\begin{array}{c}\text { Volme Thaded } \\
(\% \text { 'lotal })\end{array}$} & \multicolumn{3}{|c|}{ Discounted Present Value of Surplus, $1993 \cdot 2013$} \\
\hline & & & Producers & Consmmers & 'Total \\
\hline 1993 & $\sim^{b}$ & $\uparrow^{d}$ & & & \\
\hline 2013 & $\sim c$ & $\sim$ & 丹( $\mathrm{NL}, \uparrow \mathrm{MW})$ & 1 & $\uparrow$ \\
\hline \multicolumn{6}{|c|}{ Increasing the cost of the backstop technology to $8100 /$ ton } \\
\hline & \multirow{2}{*}{$\begin{array}{l}\text { Average } \\
\text { 'lip lee }\end{array}$} & \multirow{2}{*}{$\begin{array}{c}\text { Volume lhaded } \\
\text { (\% Total) }\end{array}$} & \multicolumn{3}{|c|}{ Discounted Present Value of Suplus, 19932013} \\
\hline & & & Producers & Colsumess & Tolal \\
\hline 1993 & $\uparrow \uparrow "$ & $\uparrow$ & & & \\
\hline 2013 & $\Uparrow \Uparrow$ & $\sim$ & 丹t (wide variation) & $\Downarrow$ & 1 \\
\hline
\end{tabular}

Notation: $\uparrow(\downarrow)$ : small increase (decrease) of less than $5 \%$, $\uparrow(\downarrow)$ : increase (decrease) of $5-10 \%$; $\uparrow$ 作 (thl): substantial increase (decrease) of more 1 han $10 \% ; \sim$ : nogligible.

a Nost states now we backstop lechnology.

b Fes derease in lhe Northeast and morease in the Midwest.

Crees increase relatively less in the Northeast than in the Midwest compared with the baseline.

d.argely within state.

Clees increase in all states; double in the Midwest.

Moreover, the model enables us to study these effects over time. For example, if transportation costs dedine or the cost of the backstop techology increases, do states export more waste in the short run and save their own in-state disposal capacity for the 
future? Table 6 summarizes the results of the sensitivity tests for 19932013 , at which time backstop technologies are used at all disposal sites.

\subsection{Reducing price elasticity of demand 24}

More inclastic demand (averaging - .01 across states) results in a small increase in the average tip fee compared with the baseline. Total waste flows in 1993 increase about $4 \%$ over the baseline and the volume of waste traded increases about $15 \%$. The backstop technology is now used in some states (the backstop was not used in $1993 \mathrm{in}$ the baseline results). The pattern of trade is not affected the increase in traded waste oceurs between states that already trade in the baseline model. The largest effect of reducing the price elasticity is on surph measures. As expected when demand becomes more inclastic, all else equal, total surphus increases. Tr our model amost all of the increase acenes to consumers. The increase in the total surph and in consuner supplus is on the order of tenfold in all states. Producer surplus increases about $4 \%$

\subsection{Increasing the discount rate}

Increasing the discount rate (that is, reducing the discount factor) canses the initial shadow value of future resoures to decline. When the discount rate increases from $5 \%$ to $10 \%$ average tip fees fall substantially, about $30 \%$, in the first year of the model's operation. Fees decline in all states. The total volume of waste in interstate flows increases $10 \%$ and the mumber of trading partnes increases by one. This increase in the discount rate reduces total suplus over the lifetime of the model by $25 \%$. Produce: surplus falls about $30 \%$, due to the reduction in tip fees, and consumer surphus falls alout: $20 \%$

\subsection{Reducing transportation costs}

A $50 \%$ reduction in transportation costs, from 11 cents to 5 cents per ton per mile: results in only a negligible change in the unweighted average tip fee but wide differences in the tipping fees across states. In 1993 , the fee decreases as wuch as $20 \%$ in the Northeast and increases on the order of $30 \%$ in the Midwest. Thus, tipping fees are bid up in states which increase their imports of waste due to the reduction in transportation costs, and the fees decline in exporting states. Although such differences would be expected as a result of a decline in transportation costs, the size of the changes among states may be due in part to our assumptions about the locations of landfills and waste generation. We also might expect trading volumes to change, but they inerease only slightly (again, probably due to our assumptions about landfill/waste generation locations). The number of trading partiners increases by one.

The reduction in transportation costs generates very little change in overall surplus it increases less than 1\%. Consumer surplus increases about $1 \%$ in most states. The small change in supphs is explained by the fact that total tansportation costs are small compared with the size of surplus in the model. As might be expected given the changes in tip foes, changes in producer surplus vary markedly across regions. There is a decline

21 We reduce domald price elasticity by decreasing the $B$ parameter in (2), thus rotating the initial inverse demand curve at its hormontal miercept so that it becomes stepper. 
of 20 to $40 \%$ in the Northeast and an increase of $10 \%$ in some Midwest states; total produces sumplus increases about $5 \%$.

\subsection{Increasing the cost of the backstop technology (to a uniform cost of $\$ 100$ across states)}

Our baseline model is quite flexible in allowing us to specify different backstop technologies, each with its own marginal operating cost and transportation cost to various cities. In sensitivity tests we find that the results are sensitive to changes in the cost of the backstop technology. Here, we increase the backstop cost to $\$ 100$ for all states. ${ }^{25}$ We also assume that the same producers own the backstop facilities as well as the landfills. The increase causes the average tip fee to increase; in 1993, this increase is aloove $60 \%$. It increases in all states and doubles in the Midwest, as we would expect in response to the now-more-expensive substitute disposal option represented by the backstop. Although the total waste flow falls about $3 \%$ in response to the price effect, trading volume increases $17 \%$ and a new trading partner is added. The backstop is not used in any stiate.

Over time, in this simulation, there is very little change in the perent of interstate shipments as a perent of total waste generation. However, there are substantial differenes in the handling of waste. For example, Northeast states reduee interstate shipments and use their own landfils for more of their waste, and there are many trads anong Midwest states (MO ships to KS, OHCi ships to WV. OHCl ships to PA. and TNI ships to ()HCi). The change in backstop cost reduces total surplus about $3 \%$. Consmomes suplus falls about $6 \%$. Producer suplus increases about $65 \%$, however, with state variation from $10 \%$ to $100 \%$.

\subsection{Summary of sensitivity results}

The model's predicted tip foes change only negligibly when we reduce demand elasticity. but change widely among states with the change in transportation costs. We seo larger swings in surplus measures. As would be expected, discounted consumer surplus is very sensitive to the change in demand elasticity and the discount rate. Discounted producer surplus is sensitive to changes in the costs of transportation and the backstop technology. These suplus effects also vary widely among geographic regions; for: instance, supplus is transferred from producers in the Northeast to those in the Midwest when transportation costs decline. Perhaps most important for our focus on interstate flows, however, are the effects of the sensitivity tests on the volume traded and the mumber of interstate Hows. Oux: simulations suggest that when the demand clasticity, disconnt rate, and tansportation costs are modified, the volume taded can increase initially but there is only one additional trading partner. Over time, there is small or negligible change in the volume traded and no change in the number of trading partners. The response to changes in transportation costs may be heavily dependent on the assumption we made to economize on data collection about the locations of landfills and of the origin of the waste generated.

25 Arguably, one fom of backstop would be a disposal option avajalble to all states at some brge cost. (such as disposal of waste in outer space, perhaps). If so, then equalizing the cost of the backstop across states is appropriate. 


\section{Policy Simulations}

The primary purpose of our model is to understand the implications of various proposed policies to restrict interstate trade in MSW. In this section we consider several scenarios. We impose each of the following restrictions:

- Surcharges: a one-dollar surcharge applied to each ton of imported waste.

- Quantitative restrictions: volume-based restrictions on the amount of waste exported.

- Surcharges and quantitative restrictions: a combination of a one-dollar import sulcharge and quantitative export restrictions.

- No trade: prohibition of any interstate shipments.

We model the first three of these policies based on provisions in the 1995 Senate bill restricting waste shipments (see discussion in section II). Specifically, this bill proposes that importing states be permited to levy a one-dollar surcharge per ton of imports. It also proposes to require that exporting states in 1996 export to any one state no more than the greater of 1.4 million tons or $90 \%$ of the amount exported to the state in 1993 ; in 1997, the limit is the greater of 1.3 million tons or $90 \%$ of the amount exported to the state in 1993; and the linit is increasingly smaller amounts in subseguent years (with the restriction in 2002 and any year thereafter set at no more than 550.000 tons). ${ }^{26}$ We assume that these restrictions are perfectly enfored and all tax revene (or revome from andioning licenses to export or import) is redistributed to landfill ownes rather: than to consumers (those generating the waste). Finally, we assume in these preliminary simmations that the imposition of the new policy is perfectly anticipated.

\section{Insert figure around here}

Fig. 8. Trade under Policy Simulations.

Our primary interest is in the effects of these policies on the volume and number: of interstate shipments and on changes in the size and distribution of surplus. We summarize the results in figure 8 and table 7 . We also have results for changes in surplus among states and for changes in tip fees, which of course drive the changes in shipments and supplus. We summarize these in the discussion below (details are available from the authors). Changes in surplus are in terms of discounted present value, in 1993 dollars.

\subsection{Surcharges}

Interstate Trude: We would expect that an import surcharge would reduce imports and the amount of waste traded among states. It would raise the prices of titles to landfill capacity sold to states which formerly exported waste and would lower the prices of

\footnotetext{
26 It is not dear whether states may ship to states with which they did not trade prior to 1993 , provided that shipments meet this quantity cap. Accordingly, we model two interpretations of the caps: (1) states are subject to the cap but may trade with any state provided the quantity satisfies the cap; and (2) states are subject to the cap and camot ship to any state with which they did not trade in 1993.
} 
Table 7. Policy Simulations: Surplus Effects

\% Change Compared with Baseline

\begin{tabular}{|c|c|c|c|}
\hline & Producers & Consumers & Total \\
\hline Surdlarge & $\begin{array}{c}1 \% \\
(10 \mathrm{OHO}, \mathrm{WV}, \mathrm{IN})\end{array}$ &.$- .01 \%$ & $-.0001 \%$ \\
\hline $\begin{array}{l}\text { Hexport Restrictions: } \\
\text { Cap }\end{array}$ & 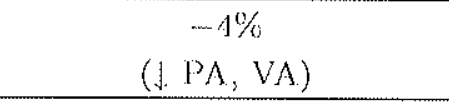 & $-.01 \%$ & $-.08 \%$ \\
\hline $\begin{array}{l}\text { Rexport Restrictions: } \\
\text { Cap and Ploor }\end{array}$ & $\begin{array}{c}-6 \% \\
(\mathrm{~J}, \mathrm{PA}, \mathrm{IN}, \mathrm{VA})\end{array}$ & $\cdots .01 \%$ & $-1 \%$ \\
\hline $\begin{array}{l}\text { Surcharge, } \\
\text { Cap and loor }\end{array}$ & $\begin{array}{c}-5 \% \\
\text { (」. PA, VA, IN WV) }\end{array}$ & $-.02 \%$ & $-.1 \%$ \\
\hline No Trade & $\begin{array}{c}-8.5 \% \\
(\mathrm{JPA}, \mathrm{OJO \textrm {H }}, \mathrm{VA}, \mathrm{WV}, \mathrm{IN})\end{array}$ & $-.08 \%$ & $-2 \%$ \\
\hline
\end{tabular}

titiles to landfill capacity in states which formely imported waste. When we impose a one-dollar surcharge on each ton of waste imported, the results are consistent with these expectations although the size of the effect is small. The perentage of waste traded declines, although by only about $4 \%$. From figure 9 , the total volume of waste traded and the number of pairs of states which trade each yeas under this policy compared with the baseline are smaller, but only slightly.

Surphus: Of all of the policy simulations, the one-dollar per ton surcharge yields the smallest reduction in total surplus. The reduction is about $\$ 2$ million, about $.0001 \%$ of the baseline sumplus. There are larger losses in total surplus in some importing; states than in exporting states. Consumer losses are largest in the Northeast, although the largest reduction there is only about $\$ 3$ per person (in NYC). Aggregate producer surphus increases about 1\%; this change in produces surplus indudes the surcharge revenue (which our model ascribes to producers). Some producers in waste importing states lose surplus even under this assumption (in OH, WV, and KS). Producers in the Nontheast gain. In many cases, the within-state consumer and producer changes offset arh other (the offet is realized only if the owners of disposal facilitios reside in the state). Separately calculated, the suphus revenue is about $\$ 280$ million.

\subsection{Volume restrictions: A cap on the volume of interstate shipments taking effect in 1996}

In this simulation we limit the maximum number of tons that can be exported by one state to another; following the tonnage limits specified in the Senate bill. As per that bill, this upper limit takes takes effect in 1996.

Interstate trude: We find that tip fees increase substantially even prior to the date at which restrictions take effect. They decline in some importing states and incrase in exporting states; the reduced fees in some states attract increased shipments. These changes yield interesting results in the size and patterns of trade. The total volume of taded waste decreases about $30 \%$, but as shown in figure 9 , the anmal volume of waste taded and the number of trading partiners increase throughout much of the entire time period. The increases begin immediately in 1993, in anticipation of the date at which 
the restrictions take effect (1996). Even when the quantity traded is less than in the baseline (for example, compare the period 2003-2010), the mumber of trades exceds those in the baseline, and there are more shipments of small amounts of waste.

Surplus: This restriction reduces surplus about $\$ 1.3$ billion. The largest loss is in producer surplus; aggregate loss in producer surplus is about $4 \%$ (about $\$ 1.2$ billion). In some waste importing states producers lose as much as $25 \%$ (in PAPi), but in other importing states, producers gain from increased shipments (for example, in WV). Aggregate consumer surplus falls about $\$ 162$ million. As in the case of the surcharge, the largest consumer surplus losses accrue in the Northeast. Consumers in some waste importing states gain.

6.3. Volume restrictions: A cap on the volume of interstate shipments and prohibition. of new trade with any state, taking effect in 1996

This simulation imposes the cap described above and prohibits any state from making any new shipments to any state with which it was not already trading in 1993. Some observers of Congressional debate suggest that this combination of a cap and a floor on trade is the proper interpretation of the Senate bill.

Interstate trade: Changes in tip fees are as in the preceding simulation, although the magnitude of the changes is less pronounced. The floor prohibiting trade among states not trading in 1993 prevents the increase in shipments of smaller volume that result when just a cap on trade is imposed. Both the number of trading partners and the cluntities of waste traded are smalles than in the basoline and in any of the other: policy simulations. Total waste taded falls about $50 \%$. Suphs: This policy results in the largest loss of surplus exept for "no trade" (discnssed below), on the ondex of $1 \%$ or $\$ 16.6$ billion. Aggregate producer and consumer sumpluses both fall, about $6 \%$ and $(01 \%$, respectively. The largest per capita losses in total surphes an in NYC, alyout $\$ 160$. Per eapita losses in total surplus elsewhere are fairly small, on the order of a few dollars. The largest producer losses are in PAPi and VA (about \$1 billion) and in TNG (about $\$ 20$ million). Producers gain in some states that export waste in the baseline model.

\subsection{Surharges and volume restrictions}

The Senate bill permits several of its provisions to be combined. In this simulation we impose a one-dollas: per: ton charge on imported waste, restrict the maximum volume of interstate shipments beginning in 1996, and prohibit trade between any states not alroady trading in 1993.

Interstate trade: The pattern of changes in tip fees is very similar to the effects of volume restrictions. The largest difference in results between this simulation and the others is that there is a spike in the number of trading partners and waste traded in alvance of 1996 . Begiming in 1996, the volume and number of trades falls below the baseline. The total volume traded decreases about $45 \%$

Surphus: The changes in surplus are similar to the changes brought about when the cap and flool volume restrictions are imposed (recal that the surcharge-only simulation resulted in a very small change in surplus). Total surphus falls about $1 \%$; the reduction in producer surplus is smallex than in the preceding simulation because we allow 
producers to keep the surplus revenues. Consumer surplus dedines about $02 \%$. The geographic patteras of surphus changes are similar to those generated by the ap and foor restrictions. Producess in PAPi, VA, ING, and WV incur the largest losses, as do consumers in the Northeast.

\subsection{No Trade}

Here we consider the effect of an immediate and permanent prohibition of interstate trade. Tip fees increase substantially in the Northeast and fall in some states that import waste as there is less demand for their landfill capacity. This policy yields the largest decline in producer, consumer, and total surplus about $8.5 \%, 08 \%$, and $2 \%$, respectively. Per capita losses in total surplus range from $\$ 370 \mathrm{in}$ PAPh and $\$ 93$ in NYC to 17 cents in IL. The total surplus loss is about $\$ 33$ billion, roughly twice the size of the loss generated by the volume-based restrictions in the two preceding simulations.

\subsection{Summamy of the policy simulations}

As we expected, restricting interstate trade by way of import surcharges or volumebased constaints reduees aggregate surplus, although producer surphs can increase. A onemdollar per ton import surcharge generates less welfare loss than volume based export restrictions or the combination of an import surcharge and export restrictions. Prohibiting trade altogether reduces welfare the most. Because we chose to mu these simulations under the assumption that each policy is fully anticipated, ou estimates of welfare loss probably understate the actual loss that would occur in the real world in which decision makers do not have porfect infomation.

In all cases, the reduction in the discounted total suplus is quite small won the order of $1 \%$, and just $2 \%$ when trade is prohibited entirely. The aggregate surphs changes per capita range from 2 cents per person under a surcharge policy and $\$ 177$ per person under volume-based restrictions, to $\$ 350$ per person if trade is prohibited entirely. Under any of the policies, however, gains or losses accuing to individual states vasy markedly. In addition, different policies result in different distributional effects between consumers and producers. Under a one-dollar-per-ton import surcharge, produces in the Midwest lose, producers in the Northeast gain, and consumers in most states lose. Under expont restrictions, producers gain in some states, such as West Virginia, and lose in the Northeast. Consumers gain in Pemsylvania and West Virginia and lose in some states in the Northeast.

Porhaps most important, we find that export restrictions can actually increase the mumber of trades as states reduce the size of shipments to any one state but increase the mmalor of small shipments to new trading partners. Moreover, an increase in trade oceus in our model in advance of the actual date on which the restrictions take effect, largely because tip fees change in response to expected new trade patterns.

\section{Conclusions}

Our model of the interstate waste maxet is rich in detail and flexibly permits a wide variety of policy simulations. We believe that it can enrich understanding of the offects of proposed policies on the waste market, particularly since these effects can be difficult 
to predict across states and over time. Despite several limitations of the model, the baseline version performs well when compared to actual data.

Our model yields two sets of results. The first pertains to the effects of pulblic policies that may affect key parameters of the waste market, such as price elasticity of demand, transportation costs, or the cost of backstop technologies. As an example, if increases in the popularity of substitutes for landfilling, such as composting, were to increase the price elasticity of demand for waste disposal, then the more likely impacts are changes in the distribution of economic surplus in the waste market rather than impacts on interstate trade. In general, we find that changes in these parameters infuence distributional gains and losses rather than the magnitude of interstate shipments.

Om: second set of results pertains directly to the interstate waste market. We find that policies proposed to restrict interstate waste shipments through import sumcharges or: volume-based restrictions reduce aggregate social welfare. However, some geographic areas, consumers, and landfill owners can bear relatively higher costs. At the same time, the surplus accuing to other landfill owners can increase substantially. Short of prohibiting trade entirely, the largest loss in discounted social surplus oceus mader a policy that restricts the maximum ftow volume between states and does not permit states to trade at all unless they had been trading prior to implementation of the poliey. In addition, and perhaps most important, some policies to lestrict exports may actually substantially increase interstate waste shipments as states export smaller volumes to mone destinations in order to meet limits on the size of shipments to any one state. If these policies are established to take effect at a future date states nespond by increasing interstate flows in anticipation of that date. 


\section{References}

[1] Chang, Ni-Bin and Richard E. Schuler. 1990. "Optimal Pricing of Sanitary Landfill Use Over Time" (mimeo).

[2] Dumbax, F. and M. Berkman. 1991. "Sanitary Landfills are Too Cheap," Waste Age, 9199.

[3] Fischer, Carolyn. 1994. "Once-and-for-All Costs and Exhaustible Resource Markets" (mimeo, University of Michigan).

[4] Fullerton, Don and Thomas C. Kimaman. 1993. "Houschold Demand for Garbage and Recycling Collection with the Start of a Price per Bag" (mimeo).

[5] Gandet, G., M. Moreaux, and S. Salant. 1997. "Intertemporal and Spatial Depletion of a Fixed Set of Landfills" (mimeo).

(6) Horfindahl, Omis C. 1967. "Depletion and Ecomomic Theory" in Mason Gaffuey, ed. Extractive Resources and Taxation (Madison: University of Wisconsin Press).

(7) Hotelling, Hasold. 1931. "The Economics of Exhaustible Resources," Journal of Political Economy, 39:2, 137-175.

[8] Jenkins, Robin. 1991. "Municipal Demand for Solid Waste Disposal Services: The Impart of User: Fees" (mimeo, University of Maryland).

[9] Kolstad, Charles. 1994. "Fotelling Rents in Hotelling Space: Produet Differentiation in Exhaustible Resource Maxkets," Joumal of Environmental Economics and Management, 26, 163-180.

[10) Laffont, Jean-Jacques and Michel Moreanx. 1984. "Bordeanx Claret Versus Gravel: A Rational Expectations Analysis," in Gerard Gaudet and Pieme Lasserre eds. Ressources Naturelles and Theorie Economique.

[11] Macauley, Molly K., Stephen W. Salant, Margaret A. Walls, and David Edelstein. 1993. "Managing Municipal Solid Waste: Advantages of the Discriminating Monopolist:" Resoures for the Future Discussion Paper ENR 93-05.

[12] MoCarthy, James E. 1995. Interstate Shipment of Municipal Solid Waste: 1995 Update (CRS Report for Congress, 95-570 ENR), Washington, DO, Congressional Research Service.

[13] Momis, Glem E. and Denise Byrd. 1990. "The Effects of Weight or Volume-Based Pricing on Solid Waste Management" (report for U.S. Enviromental Protection Agency), January.

[14] Nordhaus, William D. 1973. "The Allocation of Energy Resources," Brookings Papess on Economic Activity, 3, 529570.

[15] Pindyck, Robert S. 1978. "The Optimal Exploration and Production of Nomenewable Resources," Jourmal of Political Economy, 86:5, October, 841861.

[16] Ready, Mark J. and Richard C. Ready. 1995. "Optimal Pricing of Depletable, Replaceable Resources: The Case of Landfill Tipping Fees," Joumal of Environmental Economics and Management, $28: 3,307 \cdots 323$. 
[17] Repa, Edward. 1993. "Interstate Movement of Muxicipal Solid Waste - 1992 Update," Waste Age Magazine (Special Report).

[18] Roberts, Kevin W.S. and Martin L. Weitzman. 1980. "On a General Approach to Scarch and Information Gathering" (mimeo).

[19] Salant, Stephen W. 1995. "The Economics of Natural Resource Extraction: A Primer for Development Economists," The World Bank Research Observer, 10:1, Fobruary, 93111.

[20] Sigman. Hilary. 1994. "The Cost of Municipal Solid Waste Reduction" (mimeo).

21] Skmmat\%, Lisa and Cabell Breckinridge. 1990. "Variable Rates in Solid Waste," in Handbook for Solid Waste Officials, vol. 2, EPA 530-SW-90-084B, June.

[22] Weitzman, Martin L. 1976. "The Optimal Development of Resource Pools," Journal of Economic Theory, 12:3, 351 364.

[23] Werty, Kemneth L. 1976. "Economic Factors Infuencing Houscholds" Production of: Rofuse," Journal of Environmental Economics and Management, 2, 263-272.

[24] Woods, Randy. 1995. "Carbone Plus One: How Much Flow Will be Controlled?:" Waste Age. May, pp. 7990.

[25] Woods, Raudy 1997. "Waiting for Depot?" Waste Age, Jamary, pp. 60 71. 


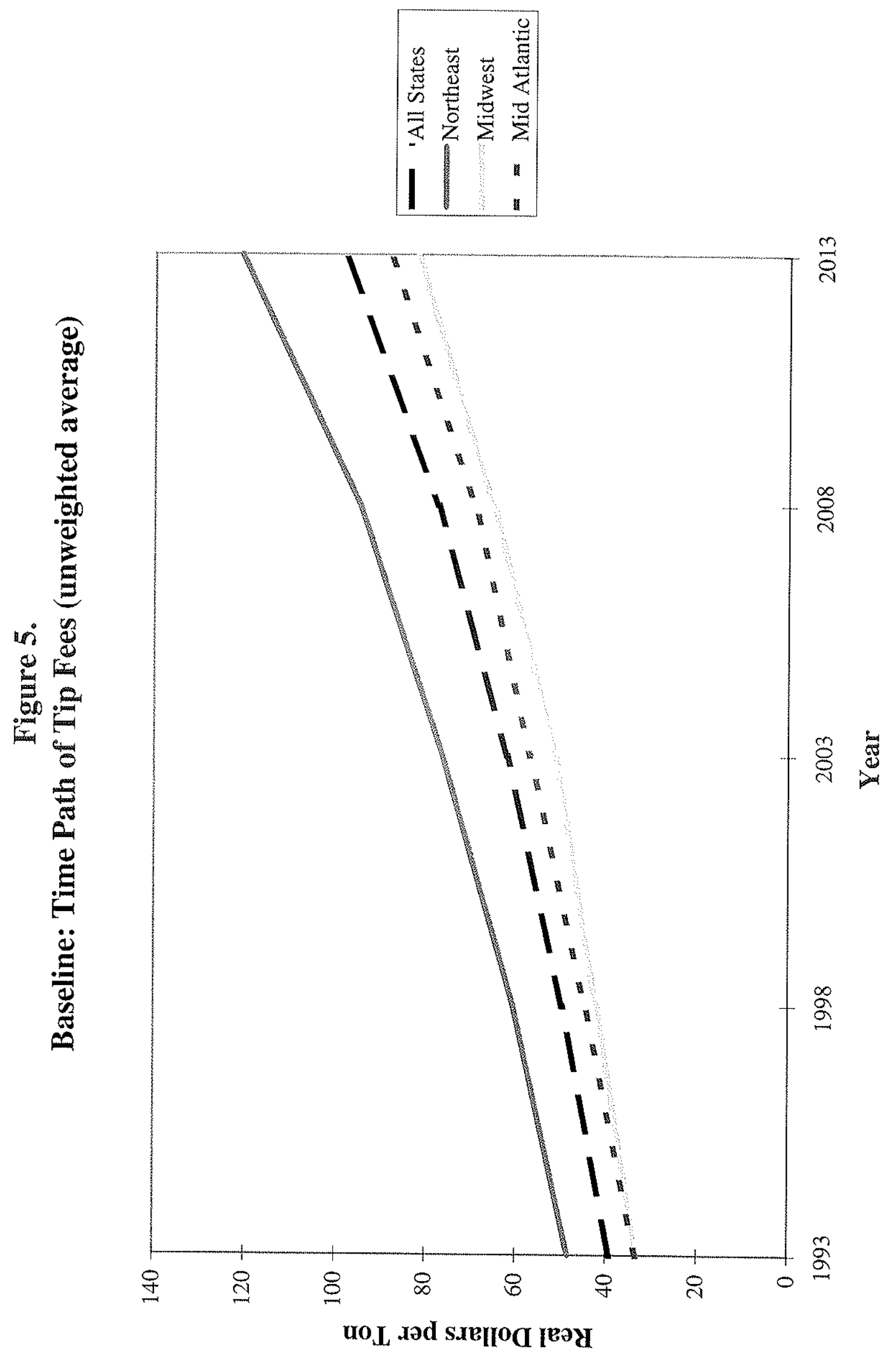




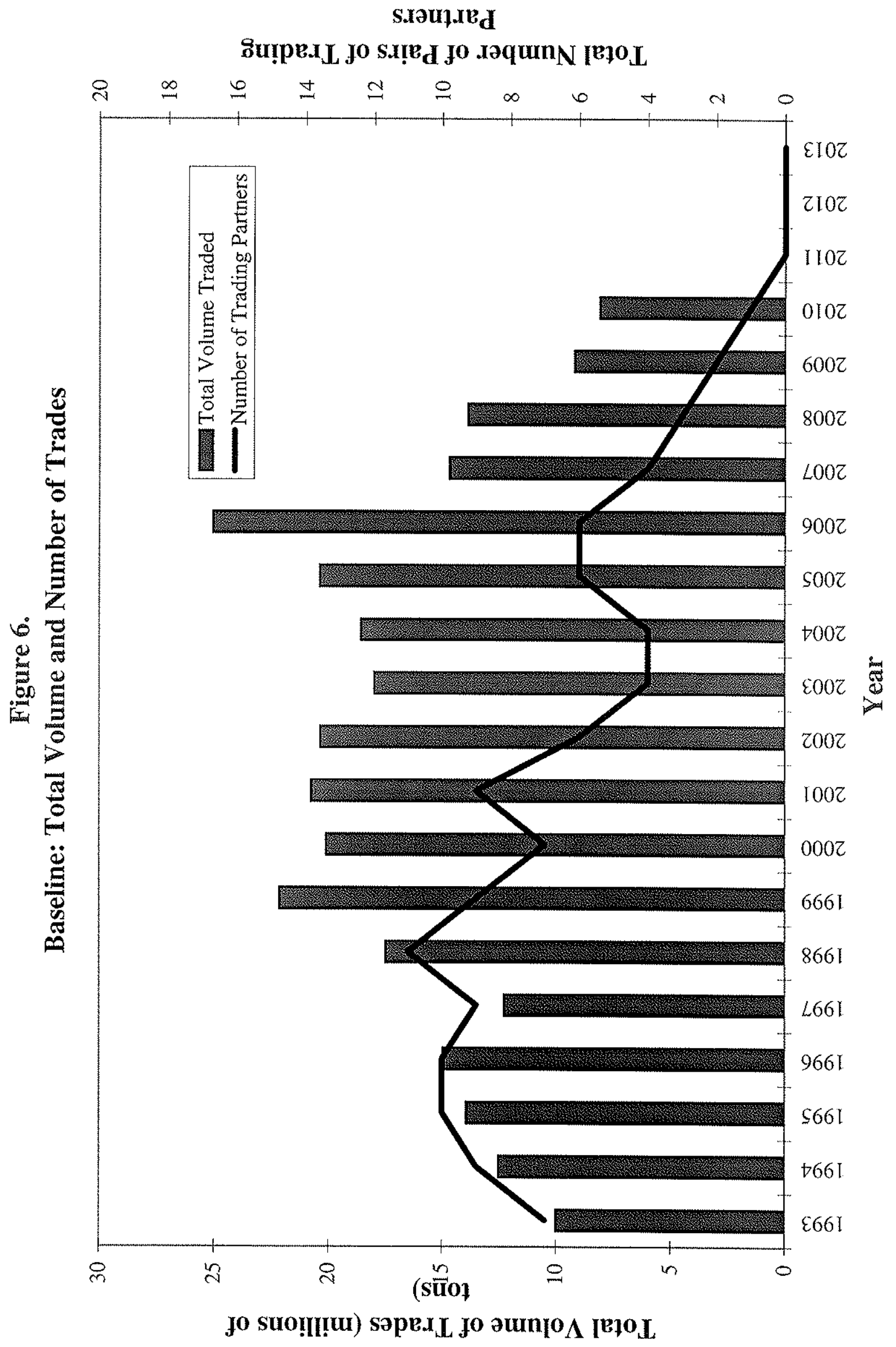




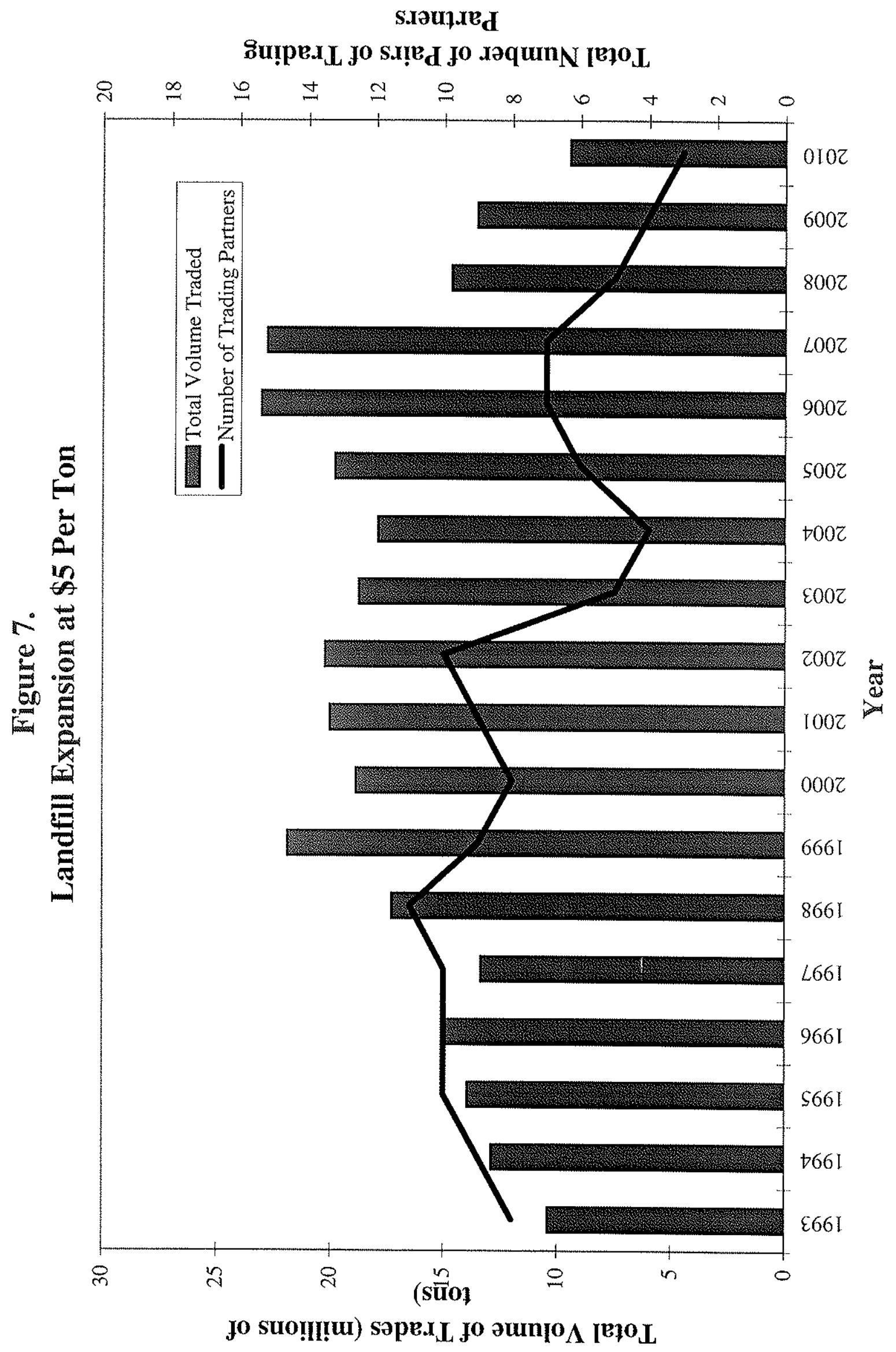


Figure 8.

Trade Under Policy Simulations

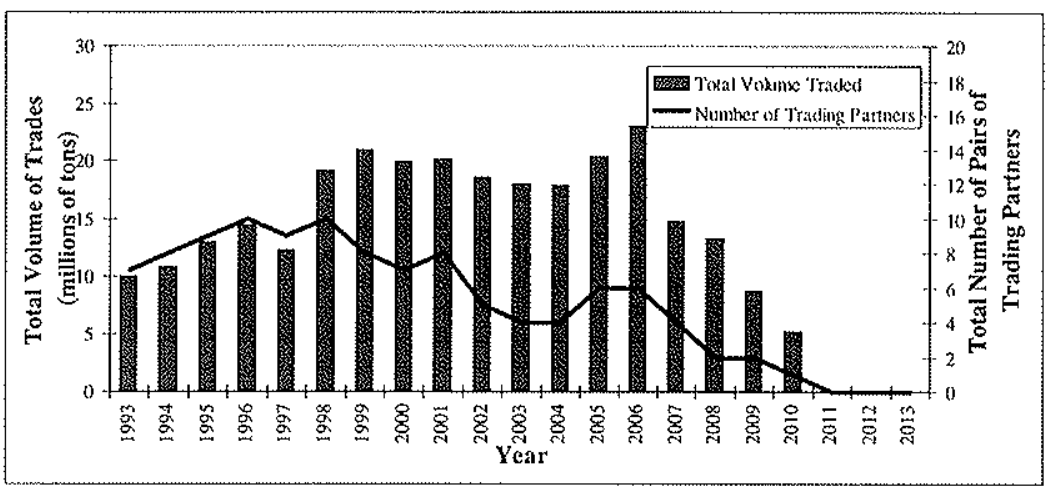

(a) Surcharge

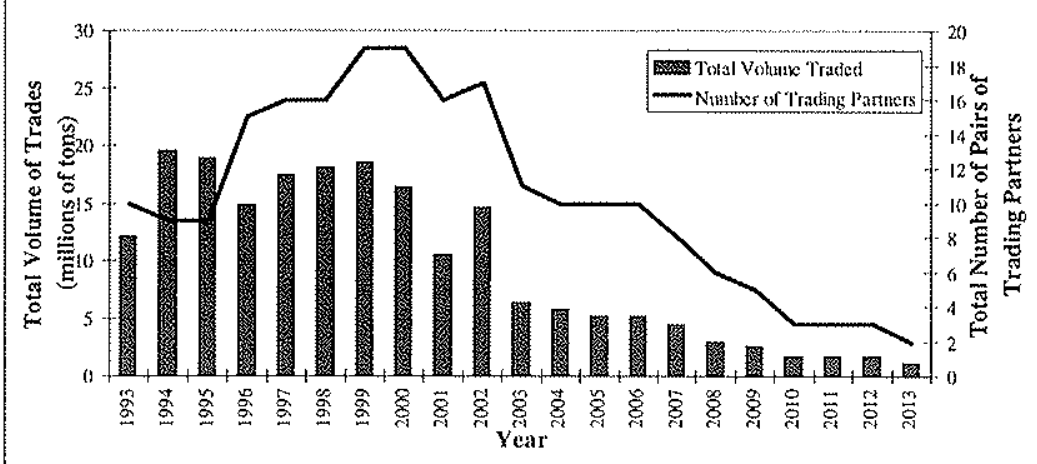

(b) Export Restrictions, Cap Only

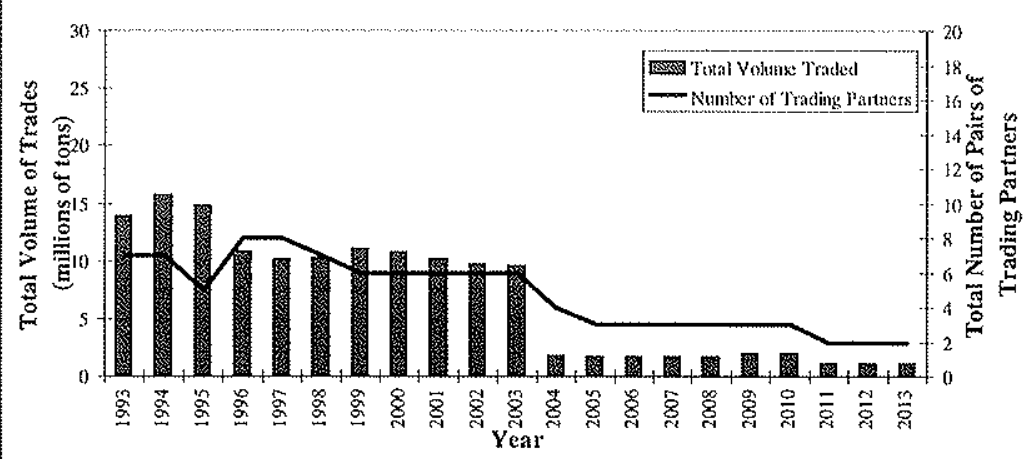

(c) Export Restrictions, Cap \& Floor

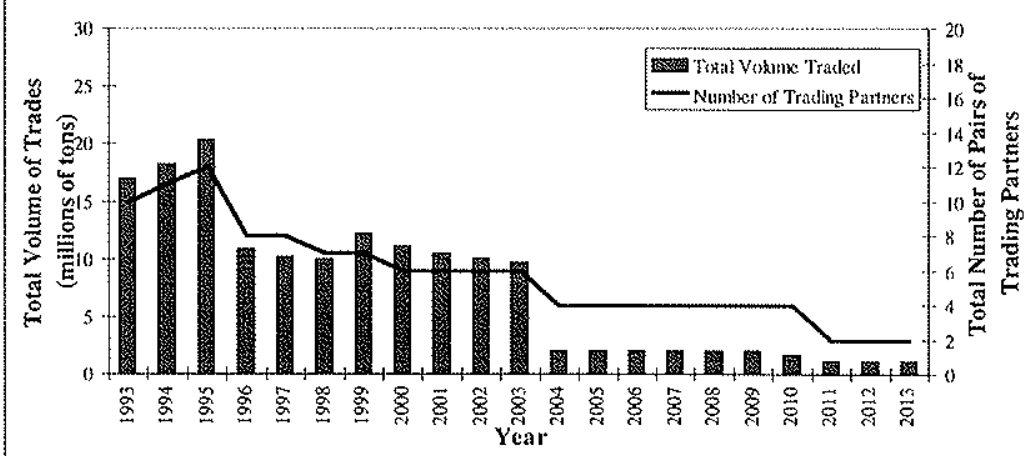

(d) Surcharge \& Export Restrictions 


\section{RELACION DE DOCUMENTOS DE FEDEA}

\section{COLECCION RESUMENES}

96-02: "Evidencia empírica de sustituibilidad entre los componentes sectoriales del ahorro nacional en algunos países de la Unión Europea", Isabel Argimón.

96-01: "El mercado de depósitos español (1985-1994): Bancos versus Cajas de Ahorro", Juan Coello.

\section{TEXTOS EXPRESS}

97-01: "La cuestión de las pensiones", José A. Herce.

96-02: "La Unión Económica y Monetaria en Europa", encuesta coordinada por: Miguel Sebastián y Simón Sosvilla.

96-01: "La Seguridad Social del siglo XXI y la reforma de las pensiones de 1996", José A. Herce.

\section{DOCUMENTOS DE TRABAJO}

97-07: "Spatially and intertemporally efficient waste management: The costs of interstate flow control", Eduardo Ley, Molly K. Macauley y Stephen W. Salant.

97-06: "Are there any special features in the Spanish business cycle?, Luis Puch y Omar Licandro.

97-05: "Los factores específicos del paro en Andalucía" Juan F. Jimeno.

97-04: "The effects of minimum bargained wages on earnings: Evidence from Spain", Juan J. Dolado, Florentino Felgueroso y Juan F. Jimeno.

97-03: "Convergence in social protection benefits across EU countries", Javier Alonso, Miguel Angel Galindo y Simón Sosvilla.

97-02: "Public-good productivity differentials and non-cooperative public-good provision", Eduardo Ley.

97-01: "Paridad del poder adquisitivo: Una reconsideración", F. J. Ledesma, M. Navarro, J. V. Pérex y S. Sosvilla.

96-28: "Urbanization and growtl", Juan J. de Lucio.

96-27: "Efectos macroeconómicos del mercado único europeo: Un análisis basado en el modelo HERMIN", Simón Sosvilla-Rivero y José Antonio Herce.

96-26: "Capacity and access pricing strategies: An argument for the liberalization of telecommunication infraestructure", A. Urbano, G. Olcina y Y. Tauman.

96-25: "La reforma de las pensiones en España: Aspectos analíticos y aplicados", José A. Herce.

96-24: "Transitional effects of a pension system change in Spain", José M. Bailén y Joan Gii.

96-23: "Convergencia real en la Unión Europea: Un and́lisis de series temporales", Vicente Esteve y Vicente J. Pallardó.

96-22: "Monetary Union and european unemployment", José Viñals y Juan F. Jimeno.

96-21: "El equilibrio financiero de un sistema de reparto de pensiones de jubilación: Una aplicación al caso español", Juan F. Jimeno y Omar Licandro.

96-20: "The effects of migration on the relative demand of skilled versus unskilled labour: Evidence from Spain", Juan J. Dolado, Juan F. Jimeno y Rosa Duce.

96-19: "The causes of Spanish unemployment: A structural VAR apporach", Juan J. Dolado y Juan F. Jimeno.

96-18: "La Unión Económica y Monetaria en Europa: Una encuesta entre expertos académicos y de mercados", Miguel Sebastián y Simón Sosvilla.

96-17: "Externalities and growth in the Spanish industries", Berta Moreno.

96-16: "Replacement echoes in the vintage capital growth model", Raouf Boucekkine, Marc Germain y Omar Licandro.

96-15: "La industria en las Comunidades Autonomas: 1978-1992", José A. Herce, Juan J. de Lucio y Ana Goicolea. 